PontIFícIA UNIVERSIDADE CATÓLICA DO RIO DE JANEIRO

\title{
Otimização dos Custos Logísticos de Transporte na Empresa XPTO Estudo de Caso
}

\author{
Eduardo Erthal Marins
}

Trabalho de Conclusão de Curso

Centro de CIÊnCIAS SOCIAIS - CCS

DEPARTAMENTO DE AdMINISTRAÇÃO

Graduação em Administração de Empresas 
Eduardo Erthal Marins

Otimização dos Custos Logísticos de Transporte na Empresa XPTO

Estudo de Caso

Trabalho de Conclusão de Curso

Trabalho de Conclusão de Curso, apresentado ao programa de graduação em Administração da PUC-Rio como requisito parcial para a obtenção do titulo de graduação em Administração.

Orientador: Isao Nishioka

Rio de Janeiro

Novembro de 2016. 
O objetivo da logística é prover aos clientes os níveis de serviços por ele requeridos, com a entrega do produto certo, no lugar certo, no momento certo, nas condições certas e pelo custo certo. (FARIA E COSTA, 2005). 


\section{Agradecimentos}

Agradeço a meus pais por sua ajuda e apoio incondicionais de sempre.

A meus colegas de faculdade, por me ajudarem a juntos conseguirmos conquistar nossos objetivos.

À minha madrinha, que não poupou esforços em me receber no Rio de Janeiro para a realização do curso.

Ao Professor Isao Nishioka, um agradecimento especial pela atenção, disponibilidade, cuidado e sabedoria de sempre e pela orientação neste trabalho de conclusão de curso. 


\section{Resumo}

Marins, Eduardo Erthal. Otimização dos Custos Logísticos de Transporte. Estudo de Caso. Rio de Janeiro, 2016. 50 p. Trabalho de Conclusão de Curso - Departamento de Administração. Pontifícia Universidade Católica do Rio de Janeiro.

A logística é considerada atualmente um componente estratégico para as empresas pelas oportunidades que oferece no gerenciamento da cadeia de suprimentos. No entanto, os custos das atividades logísticas são altos, impactando nos resultados financeiros. Não por acaso, o gerenciamento dos custos logísticos é considerado imprescindível. Os custos logísticos de transporte constituem maior parcela dos custos logísticos totais das empresas e o transporte rodoviário tem maior representação nesse processo. A pesquisa aborda estratégias de otimização dos custos logísticos de transporte na Empresa XPTO, que utiliza o modal rodoviário como meio de distribuição de seu produto.

\section{Palavras- chave:}

Logística, custos logísticos de transporte, análise dos custos do transporte rodoviário da Empresa XРTO.

\section{Abstract}

Marins, Eduardo Erthal. Optimization of Transport Logistics Costs. Case Study. Rio de Janeiro, 2016. 50 p. Trabalho de Conclusão de Curso Departamento de Administração. Pontifícia Universidade Católica do Rio de Janeiro.

Logistics is currently considered a strategic component for companies the opportunities it offers in managing the supply chain. However, the costs of logistics activities are high, impacting the financial results. Not coincidentally, the management of logistics costs is considered essential. Transport logistics costs are larger share of total logistics costs for businesses and road transport have increased representation in the process. The research discusses optimization strategies logistics transport costs in the Company XPTO, which uses road transport a ways of distributing its product.

\section{Key-words}

Logistics, logistics transport costs, analysis of road transport costs in Company XPTO. 


\section{Sumário}

1 O tema e o problema de estudo 1

1.1. Introdução ao tema e ao problema do estudo 1

1.2. Objetivos do estudo 2

1.3. Delimitação e foco do estudo 3

1.4. Justificativa e relevância do estudo 3

2 Revisão de literatura 4

2.1. Logística: evolução, conceitos 4

2.2. Custos logísticos 9

2.3. Matriz de transportes 14

$\begin{array}{ll}\text { 2.3.1. Modal rodoviário e seus custos } & 18\end{array}$

3 Métodos e procedimentos de coleta e de análise de dados do estudo 23

3.1. Método de pesquisa utilizado 23

3.2. Procedimentos e instrumentos de coleta de dados 23

3.3. Tratamento e análise dos dados coletados 24

3.4. Limitações do estudo 24

4 Apresentação e análise dos resultados 25

4.1. A Empresa 25

4.2. Descrição dos resultados 26

4.2.1. Respostas do gerente de logística e análise 26

4.2.2. Respostas dos caminhoneiros e análise 30

5 Conclusões e recomendações para novos estudos 34

5.1. Comentários Finais e Recomendações 35

6 Referências Bibliográficas 36

$\begin{array}{ll}\text { Apêndice } 1 & 39\end{array}$ 


\section{Lista de figuras}

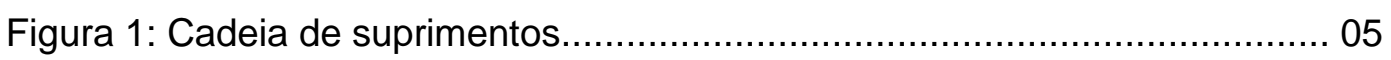

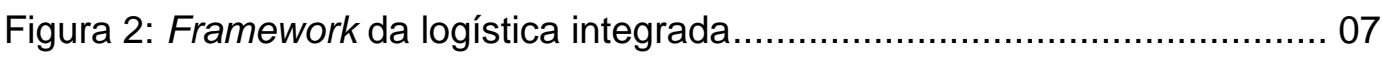

Figura 3: Ciclo de reutilização da logística reversa........................................... 08

Figura 4: Distribuição modal da matriz brasileira de transportes de carga .......... 14

\section{Lista de Tabelas}

Tabela 1: Participação do modal rodoviário em diferentes países ...................... 18

Tabela 2: Classificação do modal rodoviário quanto à disponibilidade .............. 19 


\section{0 tema e o problema de estudo}

\subsection{Introdução ao tema e ao problema do estudo}

A logística remonta às mais antigas épocas na história da humanidade, relacionando-se à movimentação e comercialização de diferentes mercadorias/recursos. Ganha grande impulso no meio militar durante as guerras pelas necessidades dos exércitos de planejar, de alojar e deslocar as tropas e seus devidos suprimentos - armamentos, veículos, alimentos, medicamentos etc. Visando operações eficientes e eficazes nos campos de batalha para o enfrentamento dos inimigos e obtenção de vitórias, há séculos os militares estudam e desenvolvem sistemas logísticos. (BULLER, 2012).

Após a Segunda Guerra Mundial, já na década de 1950, a logística passou a ser estudada nos cursos de Engenharia e Administração de Empresas dos Estados Unidos. Nessa época, os conceitos de logística militar foram transpostos para os negócios de modo sistêmico, expandindo o papel desta disciplina para além de ser apenas um apoio operacional. (BULLER, 2012).

Desde então, e com a evolução da aplicação da logística no âmbito empresarial, atribui-se aos sistemas logísticos organizacionais uma fonte de vantagem sobre a concorrência, sobretudo diante de um ambiente de negócios altamente competitivo.

Sendo um campo ainda em expansão, como informa Ballou (2007), a logística é vista hoje como um componente estratégico pelas oportunidades que pode proporcionar para as empresas na gestão de sua cadeia de suprimentos. (BULLER, 2012). Ela agrega valor de lugar, de tempo, de qualidade e de informação à cadeia produtiva. (NOVAES, 2014).

As operações logísticas, no entanto, têm custos elevados, que são substanciais na maior parte das empresas, por envolver custos que incidem sobre toda a cadeia logística. Nos Estados Unidos, por exemplo, o custo logístico médio de uma empresa é de cerca de $11 \%$ das vendas, representando o seu segundo maior dispêndio - o primeiro são os custos de compras. (BALLOU, 2007).

No Brasil, pesquisa desenvolvida recentemente pela Fundação Dom Cabral com 142 empresas de 22 segmentos industriais mostrou que os custos 
logísticos consomem $11,73 \%$ de sua receita e que o transporte (de longa ou de curta distância) é o fator mais representativo na estrutura desses custos. (FUNDAÇÃO DOM CABRAL, 2015).

De fato, em geral, o transporte é o elemento mais importante das empresas em termos de custos logísticos, podendo chegar a dois terços de custo logístico total. (BALLOU, 2007). No Brasil, o transporte de cargas, por exemplo, representa em média $64 \%$ dos custos logísticos de uma empresa, $4,3 \%$ de seu faturamento, e, em alguns casos, mais que o dobro de seus lucros. (WANKE, 2010).

Todos esses dados apontam para a inegável importância da gestão eficaz do sistema de transportes nas organizações.

A presente pesquisa tem como tema os custos logísticos de transporte. $O$ foco recai sobre a Empresa XPTO, do segmento de mineração, especializada na extração e comercialização de areia lavada, material amplamente utilizado no setor da construção civil.

Classificando-se como pequena empresa (de acordo com a Lei Geral das Micro e Pequenas Empresas, Lei no 123, de 2006), a XPTO tem custos logísticos que podem ser considerados elevados: cerca de $20 \%$ dos custos da atividade de extração correspondem a custos logísticos, sendo que os custos logísticos de transporte de distribuição do produto variam de 50 a $60 \%$ dos custos logísticos mensais totais da empresa. Mais de $80 \%$ das despesas da XPTO são provenientes dos custos de transporte que envolve a Região dos Lagos e a Região Metropolitana do Rio de Janeiro.

Tendo essas considerações iniciais, indaga-se: como a Empresa XPTO pode otimizar seus custos logísticos de transporte?

\subsection{Objetivos do estudo}

O objetivo principal do estudo é discutir e sugerir mudanças que possam otimizar os custos logísticos de transporte da empresa XPTO.

Os objetivos intermediários são:

- Sistematizar conhecimentos sobre custos logísticos;

- Refletir sobre custos logísticos de transportes com foco no transporte rodoviário, o mais amplamente utilizado no Brasil; 


\subsection{Delimitação e foco do estudo}

O estudo tem como pano de fundo a redução de custos logísticos. Apesar disso, delimita-se à análise da otimização dos custos logísticos de transporte tendo como foco a Empresa XPTO.

O tempo de estudo foi o período de Setembro à Novembro de 2016 e área de atuação da empresa é a região dos lagos e alguns municípios da região metropolitana.

Desta análise, excluem-se maiores aprofundamentos sobre outros tipos de custos logísticos mencionados pela literatura.

\subsection{Justificativa e relevância do estudo}

Inicialmente, a pesquisa se justifica porque os estudos sobre custos logísticos são escassos no Brasil. Apenas uma pequena parte desses estudos investiga comparativamente as práticas de gestão de custos logísticos adotadas pelas empresas e aquelas mencionadas pela literatura.Como consequência, pode servir como literatura de consulta a trabalhos similares a virem ser executados futuramente.

Também justifica a pesquisa o fato de a recente recessão da economia brasileira ter afetado significativamente o nicho de atuação da Empresa XPTO, dada a retração do setor da construção civil, motivo pelo qual esta empresa necessita reduzir seus custos logísticos de transporte, minimizando impactos financeiros, proporcionando o trabalho com margem maior de lucro e possibilitando, assim, a sua sobrevivência e competitividade no mercado.

Com a redução desses custos, acrescida de um possível reaquecimento da economia, a XPTO poderá inclusive investir em outras áreas de interesse relacionadas a seu core business. 


\section{Revisão de literatura}

Este capítulo desenvolve a revisão de literatura sobre o tema central da pesquisa. São apresentados e discutidos aspectos históricos e conceituais sobre logística empresarial e analisados os custos logísticos, com foco nos custos de transporte, além do transporte rodoviário em si, cujo peso nos custos logísticos é significativamente alto. Uma reflexão sobre medidas que otimizem os custos logísticos de transporte finaliza esta primeira parte do trabalho, que se baseia em estudos já publicados sobre o tema e que fundamenta a investigação posterior, relativa à Empresa XPTO, realizada no capítulo 3 .

\subsection{Logística: evolução, conceitos}

A logística é uma atividade muito antiga, sendo exercida basicamente para a movimentação de materiais e mercadorias necessárias à vida dos povos antigos. (BULLER, 2012).

Posteriormente, a partir do século XVIII, durante as guerras, os militares aplicaram a ideia de logística e propriamente ampliaram seus domínios em razão da necessidade de descolamento e alocamento de tropas e suprimentos diversos para a manutenção dos exércitos nos campos de batalha - de acordo com Gomes e Ribeiro (2004) a palavra "logística" vem do francês "loger", que significa alocar.

Buller (2012) afirma que aspectos logísticos como rotas de acesso para abastecimento dos alojamentos e para incursões no campo inimigo, sistemas de transporte de suprimentos, meios de acomodação de cargas e sistemas de comunicação ocupavam boa parte da tarefa dos generais, bem como o planejamento antecipado das operações e a elaboração de planos de ação para situações imprevisíveis, revelando a logística em termos estratégicos e táticos. $\mathrm{Na}$ guerra, a logística militar dava suporte às ações de campo, assegurando condições operacionais que favorecessem a vitória.

Portanto, a logística como conhecemos hoje tem uma herança militar.

A partir da década de 1950 do século passado, depois do fim da Segunda Guerra Mundial, os conceitos de logística desenvolvidos pelos militares começam a ser explorados no âmbito empresarial, em organizações industriais, 
comerciais ou de serviços: o pensamento organizacional já tinha evoluído a ponto de considerar a necessidade de alinhar os processos internos das empresas e integrá-los englobando aspectos logísticos. (BULLER, 2012).

Dessa época até a década de 1960 a logística evoluiu em termos teóricos e práticos. Nos anos 1970 houve um avanço considerável com a estruturação de seus princípios básicos e na década de 1980 a logística alcança maturidade, consolidando-se no meio empresarial daí em diante. (BALLOU, 1993).

Ao longo desta evolução surgiram conceitos importantes que fundamentam o atual entendimento da logística no campo organizacional.

O primeiro deles é o de cadeia de suprimentos, supply chain, uma rede de agentes e suas atividades que entregam produtos e serviços ao consumidor final começando do ponto onde se encontra a matéria-prima. A definição de Cavanha Filho (2001, p. 3) vai nesse sentido. Ele entende a logística como:

[...] a parte do processo da cadeia de suprimento que planeja, implementa e controla o eficiente e efetivo fluxo de estocagem de bens, serviços e informações relacionadas, do ponto de origem ao ponto de consumo, visando atender aos requisitos dos consumidores.

A Figura 1 mostra a sequência de uma cadeia de suprimentos.

Figura 1: Cadeia de suprimentos

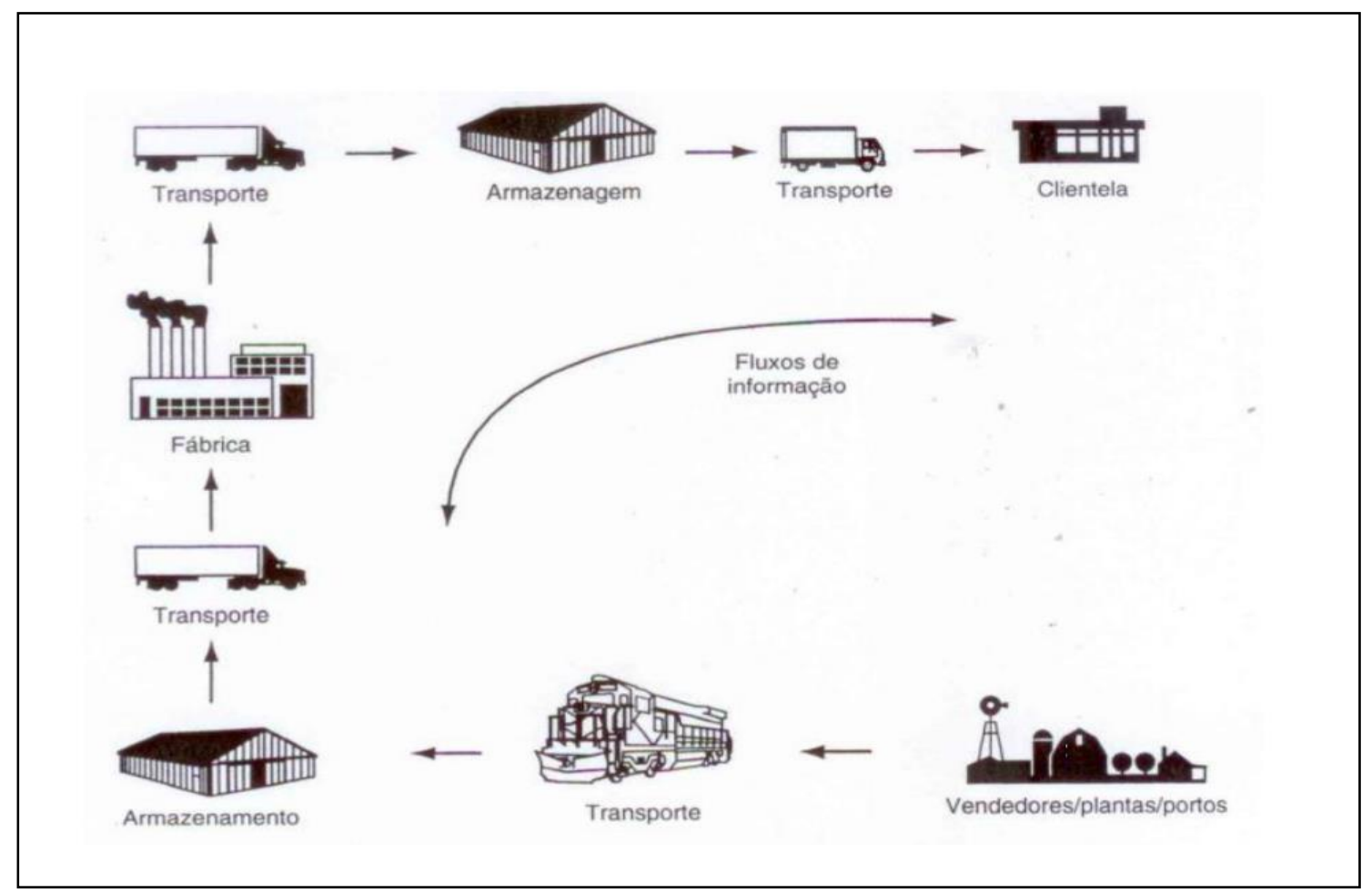

Fonte: BALLOU (2007). 
O conceito de cadeia de suprimentos coloca a logística como o processo que trata de todas as atividades de movimentação e armazenagem que facilitam o fluxo de produtos, desde o ponto de aquisição da matéria-prima até o ponto de consumo final, assim como dos fluxos de informação que colocam os produtos em movimento, com o propósito de providenciar níveis de serviços adequados aos clientes a um custo razoável. (BALLOU, 1993).

Como esse processo visa satisfazer as necessidades do consumidor final e melhorar o nível de serviço oferecido, o marketing passou a ser visto como um ferramental necessário que agrega valor ao desenvolvimento das atividades da cadeia de suprimentos - na base da logística está o entendimento de que ela deve ser vista como um instrumento de marketing, uma ferramenta gerencial, "capaz de agregar valor por meio dos serviços prestados". (FLEURY, WANKE e FIGUEIREDO, 2000, p. 31).

Na sua definição de logística, Christopher (1997) incorpora essa variável, pois a compreende como:

[...] o processo de gerenciar estrategicamente a aquisição, movimentação e o armazenamento de materiais, peças e produtos acabados (e os fluxos de informação correlatos) por meio da organização e dos seus canais de marketing, de modo a poder maximizar as lucratividades presentes e futuras com 0 atendimento dos pedidos a baixo custo. (CHRISTOPHER, 1997, p. 12).

O segundo conceito a ser destacado na evolução da logística no âmbito empresarial é o de logística integrada, que alargou a abrangência da cadeia logística. De acordo com esse conceito, a logística é vista como um sistema, um conjunto de elementos interligados que trabalham de forma coordenada com o objetivo de atingir um objetivo comum. (FLEURY, WANKE e FIGUEIREDO, 2000).

\begin{abstract}
A ideia principal neste conceito é o planejamento e coordenação do fluxo de materiais da fonte até o usuário como um sistema integrado, em vez de gerenciar, como é o caso tão frequente, o fluxo de bens como uma série de atividades independentes. Desta maneira, sob a forma de um gerenciamento logístico, o objetivo é ligar o mercado, a rede de distribuição, o processo de fabricação e a atividade de aquisição, de tal modo que os clientes sejam servidos com níveis cada vez mais altos, ainda assim mantendo os custos baixos. (ROCHA e GUIDALI, 2002, p. 2).
\end{abstract}

Segundo Fleury, Wanke e Figueiredo (2000), a logística integrada é uma ampliação da atividade logística para além das fronteiras organizacionais, na 
direção de clientes e fornecedores na cadeia de suprimentos. Impõe relacionamentos utilizando fundamentos do marketing mix (produto, preço, promoção e praça). Ou seja, todo o processo logístico, que vai da matéria-prima até o consumidor final, "é considerado entidade única, sistêmica, em que cada parte do sistema depende das demais e deve ser ajustada visando o todo". (NOVAES, 2014, p. 13).

A Figura 2 mostra um modelo conceitual de logística integrada, onde é possível observar essas características.

Figura 2: Framework da logística integrada

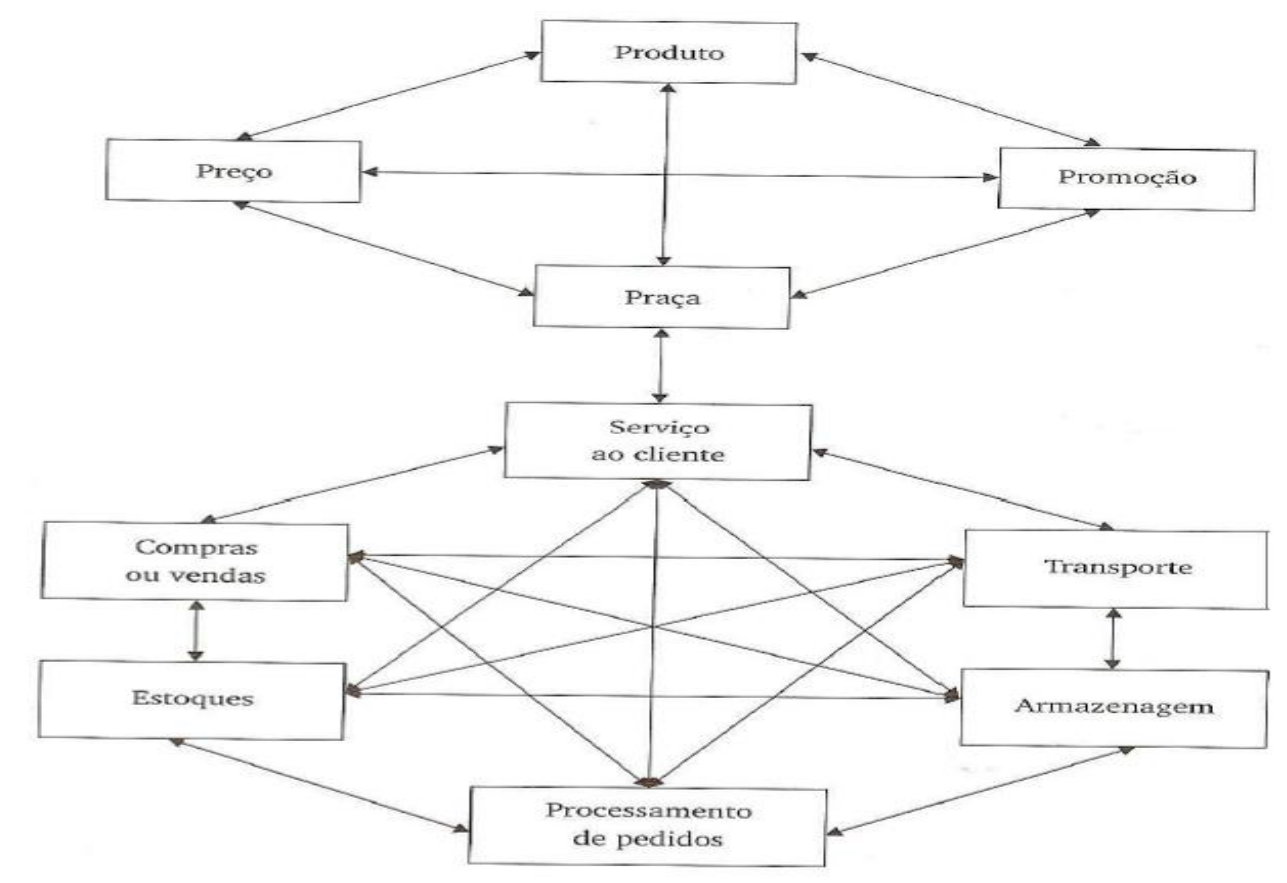

Fonte: FLEURY, WANKE e FIGUEIREDO (2000).

Apesar da sua relevância para as empresas - por otimizar o sistema logístico, reduzir custos e, consequentemente, agregar valor para o cliente (FARIA e COSTA, 2005) - a adoção do modelo integrado de logística (e seu gerenciamento) não é tão simples na prática, pois demanda o desenvolvimento de relacionamentos cooperativos com os participantes da cadeia de suprimentos, baseados na confiança, capacitação técnica e troca de informações. (FLEURY, WANKE e FIGUEIREDO, 2000).

Além disso, do ponto de vista dos custos, o modelo da logística integrada implica que a empresa assuma o conceito de custo logístico total. Pela ótica da logística integrada, os custos não podem ser vistos de forma isolada, como se fossem elementos independentes; eles possuem uma relação direta com outras 
categorias de custos. Dessa forma, "todos os custos decorrentes dos processos logísticos devem ser identificados e mensurados na análise do custo logístico total". (FARIA e COSTA, 2005, p. 46).

Segundo Cavanha Filho (2001), a sociedade está atenta para as questões do meio ambiente, reutilização e destino de dejetos de consumo. Esta realidade originou um outro conceito importante na atividade logística das empresas na atualidade, que é o de logística reversa, relacionado a ações de preservação do meio ambiente e, em última análise, à preservação da vida no planeta.

A logística reversa consiste em uma nova área da logística empresarial preocupada em equacionar a multiplicidade de aspectos logísticos do retorno ao ciclo produtivo de diferentes tipos de bens industriais, dos materiais que os constituem e dos resíduos, por meio de uma reutilização controlada do bem e de seus componentes ou da reciclagem dos materiais constituintes, dando origem a matérias-primas secundárias que se reintegrarão ao processo produtivo. (LEITE, 2003).

Leite (2003, p. 16) afirma que a logística reversa planeja, opera e controla o fluxo e as informações correspondentes do retorno dos bens de pós-venda e de pós-consumo ao ciclo de negócios ou ao ciclo produtivo por meio de canais de distribuição reversos, "agregando-lhes valor de diversas naturezas: econômico, ecológico, legal, logístico, de imagem corporativa, entre outros". Por isso, várias empresas têm aderido à logística reversa em suas atividades.

A Figura 3 ilustra o ciclo da logística reversa apontando os canais reversos de revalorização dos resíduos de pós-venda e pós-consumo.

Figura 3: Ciclo de reutilização da logística reversa

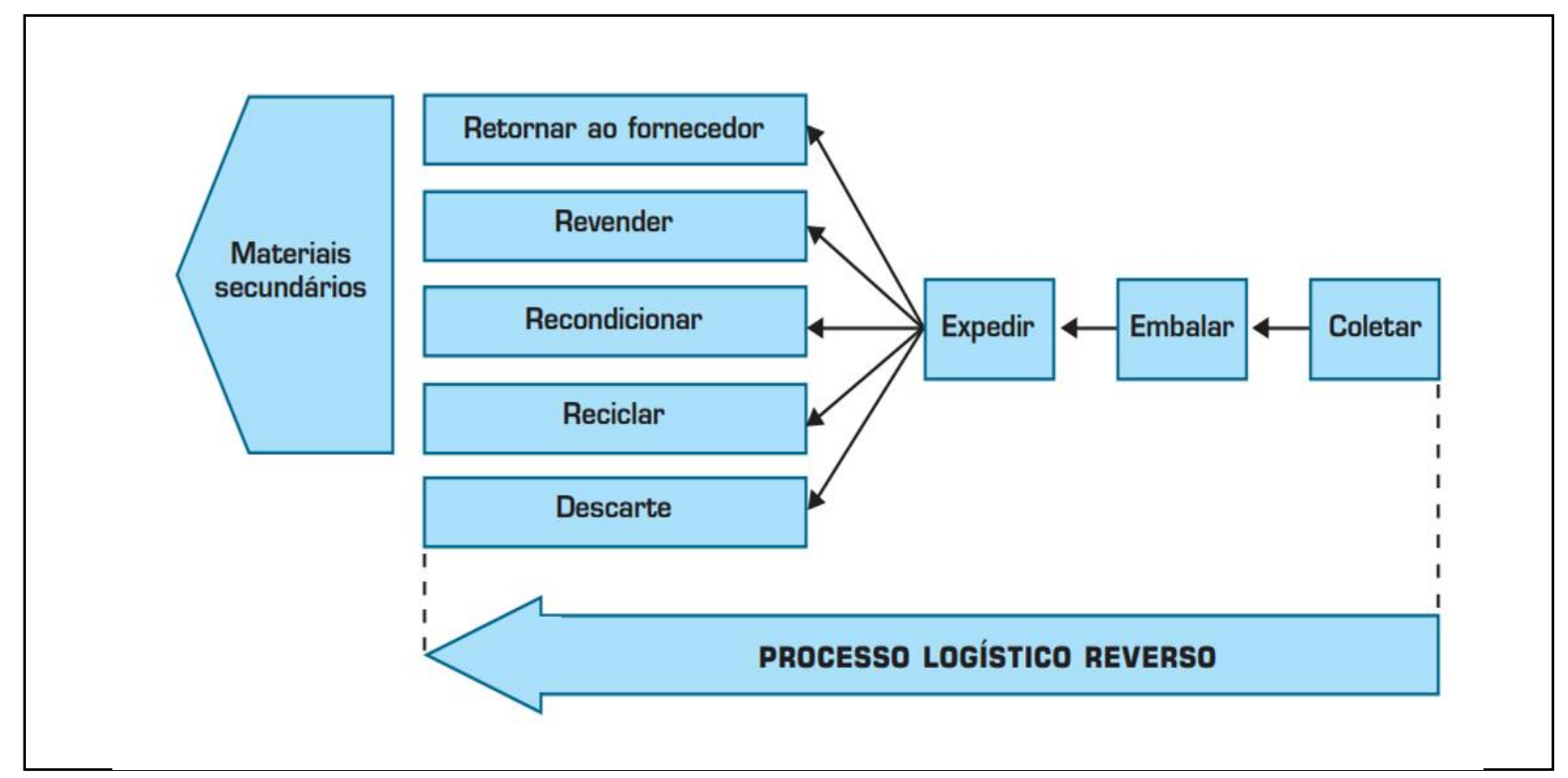

Fonte: GUARNIERI et al (2006). 
A logística empresarial é ainda uma área em expansão. (BALLOU, 2007). Mas é considerada atualmente uma estratégia imprescindível para as empresas, um elemento que as diferencia da concorrência. Ela agrega valor de lugar, de tempo, de qualidade e de informação à cadeia produtiva. Além disso, procura também eliminar do processo tudo que não tenha valor para o cliente, isto é, tudo que acarrete somente custos e perda de tempo. (NOVAES, 2014).

\subsection{Custos logísticos}

A relevância da logística é influenciada diretamente pelos custos associados à sua atividade. (BALLOU, 1993). De fato, a logística engloba inúmeros, a julgar pelas definições abaixo.

O Instituto dos Contadores Gerenciais, por exemplo, define custos logísticos como os custos de planejar, implementar e controlar todo o inventário de entrada (inbound) em processo e de saída (outbond) desde o ponto de origem até o ponto de consumo.

Para cada organização, a importância dos custos logísticos depende de alguns fatores.

\footnotetext{
Dependerá das características dos produtos, do segmento em que atuam e de como o modelo de gestão da empresa considera a Logística em relação a outras categorias de custo e objetivos. Dependerá também da localização, dos recursos da empresa em relação às suas fontes de abastecimento e distribuição, bem como do papel que a empresa pode desempenhar em um sistema logístico ou em uma cadeia de suprimentos. (FARIA, ROBLES e BIO, 2004, p. 20).
}

Apresentam-se a seguir os principais custos logísticos que integram o fluxo de materiais e bens na cadeia de suprimentos. Eles são conflitantes dentro das atividades logísticas, razão pela qual precisam ser otimizados.

As operações de armazenagem e movimentação (manuseio) referem-se à guarda temporária de produtos e materiais em estoque para posterior distribuição. Abrangem os movimentos associados ao recebimento de materiais e produtos adquiridos até o ponto de estocagem e também a retirada desses materiais até o local onde serão utilizados ou de produtos expedidos para distribuição. (FARIA e COSTA, 2005). Daí os custos de armazenagem e movimentação de materiais.

Nos custos de um armazém incluem-se, entre outros, custo de capital investido, custos com pessoal envolvido (salários e encargos sociais), custos de 
ocupação (aluguel, impostos, seguros, energia elétrica, água, telecomunicações, segurança, limpeza etc), custos de manutenção dos ativos logísticos e depreciação de equipamentos de movimentação e instalações. (FARIA, ROBLES e BIO, 2004).

Mas fatores como as características de recebimento e embarque dos materiais, volume de produtos e modo de transporte, formas de acondicionamento, necessidades de etiquetagem, mão-de-obra direta, equipamentos e recursos indiretos (como supervisão, manutenção de equipamentos, limpeza, segurança) também favorecem a determinação dos custos de armazenagem e movimentação de materiais. (CITTADIN, ZANETTE e RITTA, 2009). Por isso esses custos são significativos. Ballou (1993) afirma que eles podem absorver de $12 \%$ a $40 \%$ dos custos logísticos de uma empresa.

Na logística, as embalagens e os dispositivos de movimentação têm como principais objetivos "facilitar o manuseio e a movimentação, bem como a armazenagem, garantir a utilização adequada do equipamento/veículo de transporte, proteger o produto e prover o valor da reutilização para o usuário". (FARIA e COSTA, 2005, p. 99).

Os custos de embalagens e dispositivos de movimentação são custos de aquisição de embalagens (que envolvem matérias-primas, tais como madeira, papelão, plástico, aço, ferro ou outros materiais) e de sua aplicação, abrangendo mão-de-obra, transportes e acondicionamento de produtos. (FARIA, ROBLES e BIO, 2004).

A padronização das embalagens é recomendada porque garante a facilidade nas operações de armazenamento e movimentação, otimiza a cadeia logística e reduz o custo com transporte. (FARIA e COSTA, 2005). Também é importante em relação aos estoques, pois auxilia a identificação dos produtos, facilitando o seu reconhecimento, viabiliza a separação de mercadorias por itens e promove a qualidade do serviço ao cliente, pois traz as especificações dos produtos que são adquiridos. (CITTADIN, ZANETTE e RITTA, 2009).

O inventário é um documento que descreve os itens (produtos e materiais) constantes no estoque da empresa, servindo para seu controle. A manutenção dos inventários demanda custos para que os materiais e produtos estejam disponíveis para o sistema logístico. (FARIA e COSTA, 2005). Envolvem custos de oportunidade de investimento em estoque (custo de capital), custos de serviços de inventário (seguros e impostos sobre os estoques), custos com espaço para armazenamento de produtos, custos de riscos com deterioração, avarias, roubos e obsolescência, todos eles configurando o custo total da 
manutenção do inventário. (SOUZA, SCHNORR e FERREIRA, 2013; FARIA e COSTA, 2005).

A Tecnologia de Informação (TI) é atualmente um ferramental indispensável para que se obtenha melhor desempenho logístico, pois envolve sistemas integrados de gestão, identificação via rádio frequência, rastreamento com GPS e código de barras, entre outros aparatos tecnológicos, que proporcionam ganhos em produtividade e redução de tempo, melhoria do nível de serviço ao cliente e de confiança entre fornecedores e clientes, além de redução de custos. (CITTADIN, ZANETTE e RITTA, 2009; FARIA e COSTA, 2005).

No entanto, demanda custos, entre eles de mão-de-obra, de compra e manutenção de hardwares e softwares, transmissão de pedidos, processamento, comunicações com fornecedores e clientes, seguros, treinamento. (FARIA e COSTA, 2005).

As operações logísticas também implicam custos tributários, formado por tributos de vários tipos, tais como: imposto sobre a propriedade, sobre vendas, circulação, taxas, contribuições etc. Principalmente sobre os fluxos de produtos e serviços transacionados, os tributos incidentes sobre a empresa podem ser 0 Imposto sobre Produtos Industrializados (IPI), Imposto de Importação, Imposto sobre Circulação de Mercadorias e Serviços e sobre Prestação de Serviços de Transportes Interestaduais (ICMS), taxas e obrigações acessórias que incidem sobre operações alfandegárias (FARIA e COSTA, 2005).

Os custos com o nível de serviço ao cliente (o nível de serviço reflete a percepção do cliente quanto à qualidade de atendimento nos seus diversos aspectos) são custos incorridos para atender ao nível de serviços que os clientes esperam da empresa, entre eles: produto disponível, qualidade do produto ou serviço, entrega no prazo, implantação de novos canais de atendimento e de recursos como a internet para agilizar as comunicações. (SOUZA, SCHNORR e FERREIRA, 2013). O nível de serviço deve levar em conta o impacto das exigências dos clientes no resultado econômico da empresa. (FARIA, ROBLES e $B I O$, 2004). Portanto, no enfoque integrado da administração logística, as necessidades de serviço dos clientes devem ser satisfeitas dentro de limites razoáveis de custo. (BALLOU, 1993).

O conceito de lote relaciona-se ao trabalho requerido para preparar uma máquina específica, um recurso, centro de trabalho ou linha de produção, entre o término da fabricação de um item até o início da produção do próximo item na programação da empresa. (FARIA e COSTA, 2005). Esse processo impõe 
custos, por exemplo, na preparação da produção, na capacidade perdida devido à troca de ferramentas ou mudança de máquinas e planejamento, manuseio e movimentação de materiais, programação e expedição. (FARIA e COSTA, 2005).

Dentro do conceito de logística integrada (representado na Figura 2), o transporte adquire papel fundamental em várias estratégias da rede logística, gerando maior competitividade para a empresa. (WANKE, NAZÁRIO e FLEURY, 2000). "Um sistema de transportes eficiente contribui para intensificar a competitividade no mercado, aumentar a economia de escala na produção e reduzir os preços dos produtos em geral". (BALLOU, 2007, p. 150).

Por outro lado, o transporte representa a maior parcela dos custos logísticos na maioria das organizações. Trata-se da atividade logística mais importante "simplesmente porque ela absorve, em média, de um a dois terços dos custos logísticos". (BALLOU, 1993, p. 24).

No Brasil, os custos logísticos de transporte são fatores críticos, dada as dimensões geográficas e a infraestrutura para os transportes. (FARIA e COSTA, 2005). Eles representam em média cerca de $60 \%$ das despesas logísticas, o que, em alguns casos, pode significar duas ou três vezes o lucro de uma companhia, como é o caso, por exemplo, do setor de distribuição de combustíveis. (WANKE, NAZÁRIO e FLEURY, 2000). O transporte de carga, principal componente dos sistemas logísticos das empresas, representa em média $64 \%$ de seus custos logísticos, $4,3 \%$ de seu faturamento, e, em alguns casos, mais que o dobro de seus lucros. (WANKE, 2010).

A estrutura de custos logísticos de transporte é formada por custos fixos e custos variáveis. Os custos fixos dependem do modal utilizado e custos variáveis incluem gastos com os produtos e embalagens a serem transportados, com combustíveis, pedágios, renovação e manutenção da frota, distância dos clientes (que destaca a importância da relação volume versus distância em termos de tonelada por quilômetro), utilização ou não de centros de distribuição. (FARIA, ROBLES e BIO, 2004; SOUZA, SCHNORR e FERREIRA, 2013).

Existem fatores que influenciam nos custos logísticos de transporte. Bowersox e Closs (apud FARIA e COSTA, 2005) sugerem indicadores importantes nesse sentido, tais como a distância, o volume e a densidade dos produtos, facilidade de acondicionamento, facilidade de manuseio de materiais, responsabilidade quanto aos riscos de roubo e deterioração, condições do mercado quanto à facilidade ou não do tráfego e sazonalidade. 
Um dos principais desafios da logística é conseguir gerenciar a relação entre custo e trade-off. ${ }^{1}$ No caso dos transportes, dentre os principais trade-offs que afetam esta função, destacam-se aqueles relacionados ao estoque e ao serviço ao cliente.

Segundo Wanke, Nazário e Fleury (2000), o ponto central do trade-off entre transporte e estoque é a relação entre políticas de transporte e de estoque da empresa. Numa visão não integrada da logística, o gestor de estoques possui comumente o objetivo de minimizar os custos com estoque, sem analisar todos os custos logísticos. Este tipo de procedimento impacta de forma negativa outras funções logísticas, por exemplo, a produção, que passa a necessitar de maior flexibilidade (com lotes menores e mais frequentes, ocasionando um custo maior) e uma gestão de transporte caracterizada pelo transporte mais fracionado, aumentando de uma forma geral o custo unitário de transporte.

Outra questão ligada a este trade-off associa-se à escolha de modais porque, dependendo do modal escolhido, o tempo do percurso poderá variar em dias. A escolha dependerá do nível de serviço desejado pelo cliente e dos custos associados a cada opção de modal. (WANKE, NAZÁRIO e FLEURY, 2000).

No que diz respeito ao trade-off entre transporte e serviço ao cliente, o impacto do transporte é dos mais significativos e as principais exigências do mercado geralmente estão ligadas a: pontualidade do serviço (além do próprio tempo de viagem); capacidade de prover um serviço porta-a-porta; flexibilidade quanto ao manuseio de uma grande variedade de produtos; gerenciamento dos riscos associados a roubos, danos e avarias; e capacidade do transportador em oferecer mais que um serviço básico de transporte, tornando-se capaz de executar outras funções logísticas. (WANKE, NAZÁRIO e FLEURY, 2000).

As repostas para cada uma destas exigências estão vinculadas ao desempenho e às características de cada modal de transporte, tanto no que diz respeito às suas dimensões estruturais, quanto à sua estrutura de custos. (WANKE, NAZÁRIO e FLEURY, 2000).

Por todas essas considerações, é importante analisar a matriz de transportes brasileira, tema tratado a seguir.

${ }^{1} \mathrm{Na}$ logística, a expressão inglesa "trade-off' significa ter que escolher uma coisa em detrimento de outra, implicando um conflito de escolha e, consequentemente, uma relação de compromisso com aquilo que foi escolhido ao abrir mão do que não foi escolhido. 


\title{
2.3.Matriz de transportes
}

Matriz de transportes é a reunião dos modais de transporte utilizados em uma região ou país. Um modal corresponde à forma (ou modo) de transportar materiais e/ou produtos. Os cinco modais de transporte de cargas básicos são o ferroviário, o aquaviário, o dutoviário, o aéreo e o rodoviário. Cada um possui características operacionais específicas e consequentemente estruturas de custos específicas que os tornam mais adequados para determinadas cargas e operações. (WANKE e FLEURY, 2006; WANKE, 2010).

No Brasil, não há equilíbrio na matriz de transportes. Conforme Novaes (2014), no país não há disponibilidade de opções de modais como nos países mais desenvolvidos.

\begin{abstract}
Nossas ferrovias não formam uma rede com boa cobertura no território nacional. As opções de transporte marítimo também não são amplas. Na distribuição interna, a esmagadora parte do transporte de produtos manufaturados é constituída pelo transporte rodoviário. Para os embarcadores restam poucas opções de transporte conjugado, levando ao uso intensivo de apenas um deles, o rodoviário. (NOVAES, 2014, p. 149-150).
\end{abstract}

Isso pode ser observado na Figura 4, que ilustra a atual distribuição modal de transportes no país, estimando-se os percentuais de participação de cada modal em função das quantidades de toneladas-quilômetro-úteis (TKUs).

Figura 4: Distribuição modal da matriz brasileira de transportes de cargas
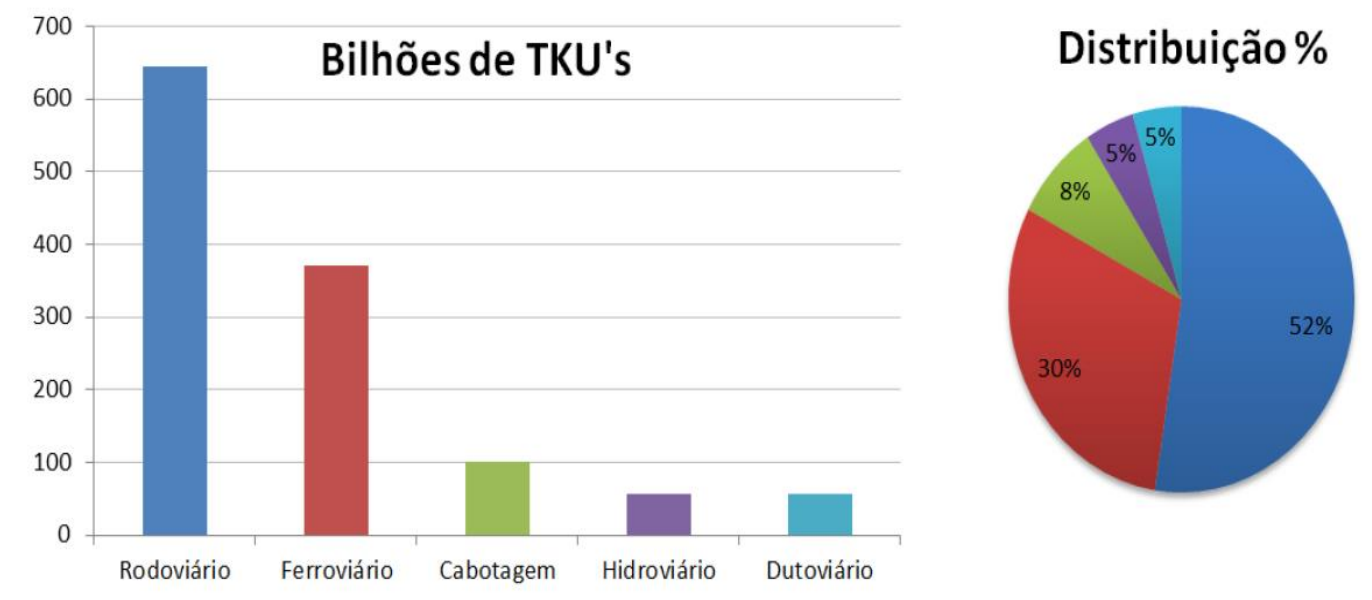

Fonte: BRASIL (2012). 
Essa matriz impacta os custos logísticos. No Brasil, uma matriz de transportes equilibrada em termos de custos e de emissões de gases de efeito estufa ocorreria com a participação maior dos modos não rodoviários. No entanto, as razões de mercado influenciam as escolhas dos modais de forma decisiva e são fortes determinantes da intensidade da movimentação de cargas tanto nacional quanto regionalmente. (BRASIL, 2012).

Para as empresas, a escolha do modal de transporte pode contribuir para economias significativas bem como para aumentar seu desempenho no que se refere ao nível de serviço prestado a seus clientes. (FARIA e COSTA, 2005).

Faria e Costa (2005, p. 89) afirmam que esta escolha é influenciada pelos fatores: "custo, tempo de trânsito da origem ao destino, risco (envolvendo a integridade da carga) e frequência (regularidade do transporte)".

Para Wanke e Fleury (2006), os critérios desta escolha devem sempre levar em consideração aspectos de custos por um lado, e características do serviço, por outro. No primeiro caso, estão incluídos: o nível de imobilização de capital em ativos fixos, a existência de economias de escala associadas ao seu uso (medidas em tonelada/quilômetro transportado, ou seja, por meio do produto do peso transportado pela quilometragem percorrida) e a presença de rendimentos crescentes ou decrescentes de escala no consumo de combustíveis, de lubrificantes e de materiais de reposição. No segundo, incluemse a possibilidade de contratação de transportadores de serviços de maior valor agregado com base em conhecimento, como, por exemplo, projetos de consultoria em logística, ou então visando a integração do transporte com outras atividades como armazenagem, manuseio de materiais etc.

Nazário (apud FLEURY, WANKE e FIGUEIREDO, 2000), defende que a escolha deve levar em conta as variáveis: velocidade, disponibilidade, confiabilidade, capacidade e frequência.

A velocidade corresponde ao tempo decorrido de movimentação em uma dada rota, também conhecido como transit time. A disponibilidade é a capacidade que um modal tem de atender qualquer par origem-destino de localidades, isto é, a quantidade de locais em que o modal se encontra presente. A confiabilidade refere-se à variabilidade potencial das programações de entrega esperadas ou divulgadas. A capacidade é a possibilidade de um modal de transporte de lidar com qualquer requisito de transporte, como tamanho e tipo de carga. Já a frequência está relacionada à quantidade de movimentações programadas. (WANKE, NAZÁRIO e FLEURY, 2000). 
Todas as sugestões mencionadas pela literatura são aqui empregadas para o desenvolvimento de uma breve análise de cada modal.

\section{a) Modal ferroviário}

O modal ferroviário é o mais apropriado para grandes volumes, mas pouco eficiente e muito oneroso para o deslocamento de pequenas quantidades. É utilizado para longas e pequenas distâncias, com baixas velocidades. (FARIA e COSTA, 2005). Tem vantagens em longas distâncias de deslocamentos maiores sobre o modal rodoviário, por exemplo. (NOVAES, 2014).

Possui tempo de entrega (velocidade) que depende do estado de conservação das ferrovias. Em relação à disponibilidade, teoricamente é aquele que ocupa o segundo lugar dentre todos (o primeiro é o rodoviário) porque depende da extensão da malha ferroviária. (WANKE e FLEURY, 2006).

Esse modal apresenta custos fixos elevados em decorrência de investimentos substanciais em trilhos, terminais, locomotivas e vagões. (WANKE e FLEURY). Para pequenas distâncias, os custos fixos não conseguem ser diluídos, onerando os fretes em demasia e tornando essa modalidade não competitiva. (NOVAES, 2014). Por outro lado, seus custos variáveis são pequenos. (WANKE e FLEURY, 2006; WANKE, 2010). O modal não é amplamente utilizado no Brasil, principalmente devido à falta de investimento em infraestrutura ferroviária.

\section{b) Modal aquaviário}

O modal aquaviário utiliza o meio aquático, natural ou artificial, para transporte de materiais e mercadorias, considerando hidrovias e cabotagem. Trata-se de um modal que opera principalmente com granéis. (BALLOU, 1993). Se for marítimo, é utilizado para grandes e médias distâncias, mas apresenta baixas velocidades. (FARIA e COSTA, 2005).

Em termos de capacidade, o modal aquaviário marítimo é a melhor opção dentre todos os modais porque não apresenta limites sobre o tipo de produto que pode transportar, assim como o volume, que pode atingir centenas de milhares de toneladas. Em relação à disponibilidade, depende da infraestrutura portuária, de terminais e de sinalização. É de baixa frequência, por causa dos grandes volumes envolvidos em sua operação. (WANKE e FLEURY, 2006).

O modal aquaviário apresenta custos fixos medianos, decorrentes do investimento em embarcações e em equipamentos (se for lacustre e fluvial, é de baixo custo). Seus custos variáveis são relativamente pequenos em razão da capacidade de transportar grandes volumes e toneladas. (WANKE e FLEURY, 2006). Segundo Ballou (2007, p. 166), o maior investimento de capital que um 
transportador aquaviário precisa fazer é em equipamentos de transporte "e, até certo ponto, em instalações terminais".

\section{c) Modal dutoviário}

O modal dutoviário transporta materiais, tais como gás, petróleo e derivados, grãos diversos, entre outros, por meio de dutos. Considerando a consistência e a confiabilidade, é a melhor opção entre todos os modais porque os dutos não são afetados por condições climáticas, congestionamentos ou verificações de segurança. (WANKE e FLEURY, 2006). Por outro lado, este modal apresenta restrições em termos de capacitação, pois o duto só trabalha com líquidos, gases e grãos. Em compensação, é eficiente do ponto de vista da frequência, pois os dutos operam 24 horas por dia, sete dias por semana, podendo ser acionados a qualquer momento. (WANKE e FLEURY, 2006).

Apresenta custos fixos elevados em decorrência de direitos de passagem, construção, estações de controle e capacidade de bombeamento. Em contrapartida, tem custos variáveis mais baixos, muitas vezes desprezíveis. (WANKE e FLEURY, 2006). Tem pouca representatividade na matriz de transporte brasileira, pois o leque de serviços e capacidades do transporte dutoviário é ainda extremamente limitado no País.

\section{d) Modal aéreo}

O grande atrativo do modal aéreo sobre os outros modais é a sua inigualável rapidez origem-destino, principalmente em grandes distâncias. (BALLOU, 2007). De fato, conforme Wanke e Fleury (2006, p. 413), o modal aéreo é o mais veloz dentre todos. Se for considerado o tempo de entrega portaa-porta, "os benefícios da velocidade no transporte aéreo são percebidos, sobretudo, nas grandes distâncias, tanto em termos relativos quanto em termos absolutos". Outra vantagem do modal aéreo é sua maior segurança quanto a perdas e danos na comparação com outros modais já que a embalagem dos produtos pode ser menos protetora. (BALLOU, 2007).

Este modal tem baixo desempenho em termos de consistência em função de sua grande sensibilidade a questões climáticas e de segurança. Além disso, apresenta restrições em relação a volumes e variedade de produtos, pois só opera com produtos seguros de pequeno e médio volumes. Em termos de custos, o modal aéreo apresenta custos fixos baixos (aeronave e sistemas de manuseio). Mas seus custos variáveis são os mais elevados: combustível, mãode-obra e manutenção. (WANKE e FLEURY, 2006). 


\subsubsection{Modal rodoviário e seus custos}

O modal rodoviário é o mais expressivo no transporte de cargas no Brasil. É o principal responsável pelo escoamento de cargas no país, participando atualmente com $52 \%$ dos fluxos de carga movimentada TKUs, o que demonstra que a economia brasileira ainda é bastante dependente do transporte rodoviário. (BRASIL, 2012). Essa dependência se verifica, inclusive, na comparação com outros países que também possuem grandes dimensões territoriais, como Rússia, Estados Unidos e Canadá.

Isso pode ser comprovado pela Tabela 1, que expõe valores percentuais relativos somente à quantidade de TKUs movimentada pelo modal rodoviário, observando-se que a participação do modo rodoviário (58\%) não deve ser confundida com o percentual da divisão modal de $52 \%$ da Figura 4, pois aquele valor é relativo ao conjunto de todos os modais (incluindo o dutoviário e cabotagem).

Tabela 1: Participação do modal rodoviário em diferentes países

\begin{tabular}{cc}
\hline PAÍSES & RODOVIA \\
\hline Rússia & $8 \%$ \\
\hline Estados Unidos & $32 \%$ \\
\hline Canadá & $43 \%$ \\
\hline Áustria & $49 \%$ \\
\hline Austrália & $53 \%$ \\
\hline México & $55 \%$ \\
\hline Brasil & $\mathbf{5 8} \%$ \\
\hline Alemanha & $\mathbf{7 1 \%}$ \\
\hline França & $81 \%$ \\
\hline
\end{tabular}

Fonte: BRASIL (2012).

No Brasil, fazem parte do modal rodoviário as transportadoras (empresas de transporte de cargas), as empresas que transportam carga própria e os autônomos, regulamentados pela Agência Nacional de Transportes Terrestres (ANTT). O modal é mais utilizado pelas micro e pequenas empresas do que pelas grandes empresas na distribuição de produtos. (WANKE e MAGALHÃES, 2012). 
A preferência das empresas pelo modal rodoviário sobre outros modais é em parte explicada por sua classificação de destaque na variável disponibilidade (correspondente à sua capacidade de atender devido à quantidade de locais em que o modal está presente). Entre nós ainda existe uma série de barreiras que impedem que todas as alternativas modais sejam utilizadas, inclusive de forma racional, sendo este um reflexo do baixo nível de investimento verificado nos últimos anos com relação à conservação, ampliação e integração dos sistemas de transporte. (WANKE, NAZÁRIO e FLEURY, 2000).

A Tabela 2 detalha essa preferência, observando-se que a menor pontuação indica melhor classificação.

Tabela 2: Classificação do modal rodoviário quanto à disponibilidade

\begin{tabular}{lccccc}
\hline \hline $\begin{array}{l}\text { Características } \\
\text { operacionais }\end{array}$ & Ferroviário & Rodoviário & Aquaviário & Dutoviário & Aéreo \\
\hline Velocidade & 3 & 2 & 4 & 5 & 1 \\
Disponibilidade & 2 & 1 & 4 & 5 & 3 \\
Confiabilidade & 3 & 2 & 4 & 1 & 5 \\
Capacidade & 2 & 3 & 1 & 5 & 4 \\
Frequiência & 4 & 2 & 5 & 1 & 3 \\
Resultado & 14 & 10 & 18 & 17 & 16 \\
\hline \hline
\end{tabular}

Fonte: WANKE, NAZÁRIO e FLEURY (2000).

Ballou (2007) vê vantagens no transporte rodoviário, preferencial para produtos semi-acabados ou acabados:

As vantagens inerentes ao transporte rodoviário são os serviços porta-a-porta, sem necessidade de carregamento e descarregamento entre origem e destino, transbordo esse inevitável nos modais ferroviário e aéreo; frequência e disponibilidade do serviço, e a velocidade e comodidade inerentes ao serviço porta-a-porta. (BALLOU, 2007, p. 155).

Para Wanke e Fleury (2006), em relação à disponibilidade, o modal rodoviário é a melhor opção entre os modais, pois quase não apresenta limites de onde chegar. Em relação à frequência, é a segunda melhor opção, vindo após o modal dutoviário. Já em termos de velocidade, o tempo de entrega no modal rodoviário depende fundamentalmente do estado de conservação das vias e do seu nível de congestionamento. 
Por outro lado, o modal rodoviário tem custos fixos e custos variáveis. No primeiro grupo incluem-se: custos com mão-de-obra (salários e encargos de motoristas, ajudantes e mecânicos, caso a empresa possua mecânicos), custos administrativos, depreciação dos veículos e equipamentos, impostos (licenciamento, Imposto sobre a Propriedade de Veículos Automotores, IPVA, seguro obrigatório), seguro do veículo e de acessórios e custo de oportunidade sobre ativos investidos. (FARIA e COSTA, 2005). Entre os custos variáveis citam-se: combustíveis, lubrificantes, pneus, acessórios, manutenção, lavagem do veículo, seguro de produtos transportados e pedágio. (FARIA e COSTA, 2005).

Mas é preciso destacar que boa parte de todos esses custos depende da quilometragem desenvolvida, da região onde o veículo trafega, do tráfego em si, das condições da via e do porte do veículo. A empresa, portanto, precisa focalizar a sua atenção para a utilização dos recursos da maneira mais eficiente possível a fim de apurar resultados econômicos positivos. (FARIA e COSTA, 2005).

Wanke e Fleury (2006) e Ballou (2007) observam que os custos da escolha pelo modal rodoviário pelas empresas são compensados pela construção e manutenção de rodovias, que dependem do poder público, muito embora esses custos sejam cobrados dos usuários na forma de impostos sobre combustíveis, pedágios e taxas.

No entanto, no Brasil, como $48 \%$ das rodovias sob jurisdição federal são classificadas como de qualidade ruim, $36 \%$ de qualidade regular e apenas $16 \%$ com qualidade boa, como $80 \%$ da malha é composta por trechos com pavimentos que possuem idade superior a dez anos, e como o estado de conservação das rodovias é considerado baixo, custos como depreciação dos veículos e equipamentos, pneus e outros assessórios, bem como a manutenção dos veículos tendem a aumentar. Ou seja, o panorama implica custos muito elevados para o setor privado na operação de veículos, sob a forma de gastos adicionais que poderiam ser evitados. (BRASIL, 2012).

A redução de custos de transporte rodoviário vem sendo discutida pela literatura, que aponta algumas medidas de otimização. Por exemplo, a adoção de frota própria ou a contratação de serviços terceirizados para as operações. (MÜLLER e MICHEL, 2001).

Segundo Ballou (1993), a utilização de frota própria tem como vantagens: maior confiabilidade no serviço, menores tempos dos ciclos de pedidos, maior capacidade de reação em casos emergenciais e maior contato com o cliente. 
Mas a análise dos custos com frota própria - a frota própria representa um grande volume de gastos - demanda separação de outros custos para ser eficiente. Recomenda-se o levantamento dos custos diretos da frota em separado dos outros custos. (MÜLLER e MICHEL, 2001).

A terceirização, por outro lado, dispensa a empresa de algumas obrigações, tais como balancear as cargas e desenvolver uma roteirização mais adequada do ponto de vista da diminuição de custos, e pode proporcionar maior flexibilidade do serviço, aumento do nível de serviços prestados ao cliente e redução do investimento em ativos. (BALLOU, 1993; FLEURY, WANKE e FIGUEIREDO, 2000).

Outra medida é a busca por soluções intermodais nos canais de distribuição (que utiliza dois ou mais modais de transporte) que possibilitem uma redução significativa de custos. (WANKE, NAZÁRIO e FLEURY, 2000).

O transporte intermodal de carga é prioritariamente utilizado para produtos como grãos, cimento, areia. Entre as vantagens de sua utilização citam-se: melhor utilização da capacidade disponível, combinações modais mais eficientes, ganhos no processo, considerando todas as operações entre origem e destino. (ANTT, 2016). Existem fatores, no entanto, que dificultam a implementação desse sistema, por exemplo, quando a distância para a distribuição do produto ou matéria-prima não é suficiente para o uso de mais de um modal ou quando o uso de outro modal, além do rodoviário, é inviabilizado em função de sua não existência no percurso entre origem e destino. Neste caso, a falta de infraestrutura local dificulta a formação de corredores multimodais.

O melhoramento da estrutura informática da empresa é mencionado como alternativa para a redução dos custos com o transporte rodoviário, pois em muitas empresas essa estrutura é precária. (MÜLLER e MICHEL, 2001).

Nesse contexto, recomenda-se o uso de sistemas computacionais específicos, por exemplo, os sistemas de roteirização e programação de veículos (conhecidos como roteirizadores) auxiliam as empresas na estruturação de rotas e são capazes de solucionar problemas de roteirização e programação de veículos de maneira satisfatória. (WANKE, NAZÁRIO e FLEURY, 2000). Muitos deles, inclusive, são disponibilizados como parte de um conjunto de sistemas integrados de gestão empresarial, como o Supply Chain Management Software, possibilitando, a partir da própria internet, ter informações sobre carregamentos, localização de veículos, previsão de horários de chegada etc. (MELO e FERREIRA FILHO, 2001). 
A busca de modais alternativos também vem sendo considerada como meio de reduzir os custos do transporte rodoviário. No Brasil, muitos empresários vêm aderindo à cabotagem, tipicamente utilizada para movimentações de longas distâncias ao longo da costa brasileira. No entanto, apesar das vantagens econômicas e ambientais, o potencial da cabotagem ainda está distante de ser completamente aproveitado, pois carece de melhor integração com outros modais, demanda maior uso de navios para viabilizar-se e também operação adequada nos portos e sua modernização. (HUBER, 2016).

A otimização relacionada a cargas e veículos é outra alternativa para reduzir os custos com transporte rodoviário. Nesse sentido, é possível: adequar o pedido ao tamanho do veículo ou fração, para que cargas de médio porte possam ser despachadas com duas ou três entregas em veículos maiores, de menor custo por tonelada e sem ociosidade; melhor utilizar o espaço interno de caminhões, gerando ganhos percentuais em termos de aproveitamento; e selecionar veículos com menor consumo de combustível. (ROCKMANN, 2015).

Finalmente Müller e Michel (2001) sugerem: qualificação e treinamento de pessoal (no caso de a empresa possuir frota própria com motoristas que fazem parte do seu quadro de funcionários); estabelecimento de uma nova política de preços e de descontos sobre o frete cobrado; e reavaliação sobre os resultados (lucro) das cargas transportadas, das rotas utilizadas e mesmo do tipo/perfil dos clientes da empresa (a falta de informações confiáveis sobre o somatório desses resultados prejudica a tomada de decisão e o próprio gerenciamento do transporte). 


\section{Métodos e procedimentos de coleta e de análise de dados do estudo}

Este capítulo informa o passo a passo para o desenvolvimento dos métodos e procedimentos aplicados a esta parte da pesquisa. São abordados o método utilizado, os procedimentos e instrumentos de coleta de dados, o tratamento e análise dos dados coletados e as limitações do estudo.

\subsection{Método de pesquisa utilizado}

O método utilizado foi o estudo de caso, definido pelo especialista Robert Yin como uma inquirição empírica que investiga um fenômeno contemporâneo dentro de um contexto da vida real. Corresponde à análise intensiva de uma situação particular ou à descrição de uma situação gerencial. (BRESSAN, 2004).

$\mathrm{O}$ estudo de caso tem entre seus objetivos permitir um exame detalhado do processo organizacional em estudo, identificando fatores particulares ao caso. Aplica-se a eventos organizacionais de interesse para a Administração de empresas, por exemplo, os impactos de mudanças em processos organizacionais. (BRESSAN, 2004).

Desenvolveu-se aqui um estudo de caso único da Empresa XPTO, com foco nos custos da logística de transporte da empresa.

\subsection{Procedimentos e instrumentos de coleta de dados}

Os procedimentos empegados obedeceram a uma sequência lógica para conectar os dados empíricos coletados às questões iniciais descritas na introdução da pesquisa e às suas considerações finais. (BRESSAN, 2004).

$\mathrm{O}$ instrumento utilizado para a coleta de dados foi o questionário estruturado, composto por questões de múltipla escolha e de escala, basicamente elaboradas a partir da revisão de literatura. A amostra é formada por três pessoas: o gerente de logística e dois caminhoneiros da Empresa XPTO (aqui denominados caminhoneiro 1 e caminhoneiro 2), selecionados segundo a sua representatividade em relação aos objetivos da pesquisa. Um questionário 
foi aplicado ao gerente (Apêndice 1) e outro, aos dois caminhoneiros (Apêndice 2).

\subsection{Tratamento e análise dos dados coletados}

Atendendo ao método utilizado e ao tamanho da amostra, os dados coletados receberam tratamento e análise qualitativos. A pesquisa qualitativa permite ao pesquisador observar características de fenômenos complexos, bem como interpretá-las, o que não é possível nas pesquisas quantitativas, as quais são centradas em dados mensuráveis. (VERGARA, 2010).

O processo de análise foi realizado com base nos assuntos tratados na revisão de literatura.

\subsection{Limitações do estudo}

A primeira limitação do estudo refere-se ao reduzido tamanho da amostra, composta por três pessoas. No entanto, considera-se que esta limitação até certo ponto pode ser compensada porque os participantes exercem funções diferentes na Empresa XPTO: um é o gerente da logística de transporte e os outros dois são caminhoneiros, aspecto que pode trazer contribuições à análise e discussão de suas respostas ao questionário.

Outra limitação está nos resultados encontrados, que, por refletirem apenas o contexto da empresa estudada, não podem ser generalizados. 


\section{Apresentação e análise dos resultados}

Este capítulo está organizado em três seções. A primeira faz uma breve apresentação da Empresa XPTO, trazendo informações relevantes para os propósitos do estudo, tais como a logística de transporte empregada na empresa, bem como os custos desse processo. Na segunda seção, os resultados da aplicação do questionário são descritos, tendo-se separado as respostas do gerente e as respostas dos dois caminhoneiros. A última seção analisa todos os resultados, discutindo-os a partir da revisão da literatura desenvolvida no capítulo 2.

\subsection{A Empresa}

A Empresa XPTO atua no segmento de mineração, sendo especializada na extração e comercialização de areia lavada, material amplamente utilizado no setor da construção civil.

Foi fundada em 2008, após seu único proprietário perceber que havia um nicho de mercado bastante promissor frente à crescente expansão da construção civil, iniciada por volta dos anos 2000. A empresa demorou praticamente cinco anos para extrair o primeiro caminhão de areia devido à dificuldade de encontrar o local apropriado para tanto (essa atividade demanda proximidade de rios e lagos) e também à burocracia relacionada às atividades minerárias no Brasil.

Com a recessão econômica do país, o setor da construção civil foi muito afetado, impactando diretamente as operações e resultados financeiros da empresa. Atualmente, ela conta com 30 funcionários, sendo dez motoristas. Seu faturamento mensal bruto é de aproximadamente 450.000 Reais.

A XPTO está baseada no município fluminense de São Pedro da Aldeia e atua na Região dos Lagos e alguns municípios da Região Metropolitana do Rio de Janeiro. Não está na internet devido à natureza de seus negócios. Poucas empresas extraem areia e fazem o transporte desse material, motivo pelo qual a maior propaganda da XPTO é o boca-a-boca.

Alguns clientes da empresa adquirem o produto diretamente no areal e o transportam - a XPTO vende a areia lavada diretamente no local da extração 
para quem tem veículo adequado para transportar a carga. Mas a grande maioria de seus clientes adquire o produto contando com os serviços de transporte da empresa.

Nesse caso, a entrega é feita por meio de frota própria, composta por dez carretas, cada uma com 25 metros cúbicos e capacidade para transportar até 25,5 toneladas de areia lavada. Devido à falta de demanda, atualmente apenas sete dessas carretas estão ativas, três estão paradas. As carretas em atividade são do ano de 2014 e as paradas de 2013. Os próprios motoristas guardam em suas casas as carretas que dirigem.

Os indicadores apresentados a seguir relacionam-se aos custos com a logística de transporte da XPTO em setembro de 2016, levando-se em conta que apenas sete carretas estão em atividade.

- As carretas rodaram $48.026 \mathrm{~km}$ no período;

- As carretas abasteceram 65 vezes no período;

- O consumo de óleo diesel no período foi de 21.147,90 litros;

- O gasto com óleo diesel no período foi de $\mathrm{R} \$ 70.724,10$;

- A média de quilometragem por litro de combustível no período foi de $2,27 \mathrm{~km} / \mathrm{L}$;

- Os custos com lavagem dos veículos no período foram de $\mathrm{R} \$ 1.050,00$;

- Os custos de manutenção dos veículos no período foram de $\mathrm{R} \$ 14.652,24$;

- Os custos com salários e comissão dos motoristas no período foram de $\mathrm{R} \$ 18.860,00$;

- Os impostos no período foram de $\mathrm{R} \$ 2.940,00$.

\subsection{Descrição dos resultados}

\subsubsection{Respostas do gerente de logística e análise}

O gerente de logística da XPTO é especializado no gerenciamento de cargas, com experiência de 15 anos. Está na empresa há oito anos, sendo responsável por todo o setor de transporte.

Pergunta 1: Entre cinco alternativas, foi solicitado que o respondente assinalasse as principais dificuldades que enfrenta no comando do setor de transportes da empresa. Duas foram assinaladas: descuido dos motoristas com as carretas e ineficácia dos métodos operacionais empregados. A primeira 
alternativa assinalada claramente transfere para terceiros uma das dificuldades apontadas pelo gerente. Quanto à segunda, ineficácia dos métodos operacionais empregados na empresa, pode ser uma dificuldade que ele próprio criou, e nesse caso, ele estaria reconhecendo o problema e fazendo uma autocrítica, mas também pode ser uma situação que ele não criou, e, nesse caso, ou ele estaria transferindo para alguém em posição hierarquicamente superior ou mesmo referindo-se a uma rotina já estabelecida e consolidada na empresa sem que se saiba exatamente quem criou.

Pergunta 2: Solicitou-se ao respondente que entre seis alternativas assinalasse com um $X$ os benefícios do modal rodoviário para a empresa e que atribuísse em números a importância de cada um desses benefícios, sendo 1 pouco importante, 2 importante e 3 muito importante. A questão foi baseada em Nazário (apud FLEURY, WANKE e FIGUEIREDO, 2000) segundo o qual a escolha de um modal de transporte deve considerar as variáveis: velocidade, disponibilidade, confiabilidade, capacidade e frequência. Acrescentou-se a variável comodidade sugerida por Ballou (2007).

O respondente não assinalou as variáveis velocidade e frequência, embora elas sejam consideradas na classificação de Wanke, Nazário e Fleury (2000) como de importância mediana (Tabela 2). Ele assinalou comodidade e disponibilidade com pontuação 3 em acordo com Wanke, Nazário e Fleury (2000) e Ballou (2007). As variáveis confiabilidade e capacidade foram pontuadas com 2 e com 1 respectivamente, o que confirma o mesmo entendimento da classificação proposta por Wanke, Nazário e Fleury (2000) na Tabela 2.

Pergunta 3: Foi solicitado ao respondente que assinalasse com um $\mathrm{X}$, entre 17 alternativas, os fatores que mais influenciam os custos do transporte rodoviário para a XPTO e que atribuísse em números o grau de influência de cada fator assinalado, sendo 1 os de menor influência, 2 os de influência mediana e 3 os de maior influência.

Três alternativas receberam pontuação 3: distância percorrida, tamanho dos lotes transportados e combustível, óleos lubrificantes, pneus, manutenção e lavagem dos veículos. Cinco alternativas receberam pontuação 2: volume e densidade do produto transportado, condições dos veículos da empresa, condições do tráfego, condições das rodovias e depreciação de veículos e equipamentos. Duas alternativas receberam pontuação 1: impostos e seguros e mão-de-obra (salários e encargos de empregados). Não foram assinalados acondicionamento e manuseio do material, roubo, danos e avarias, 
quilometragem desenvolvida, tempo do percurso entre origem e destino da carga, pontualidade do serviço, serviço porta-a-porta e pedágios.

O respondente mencionou custos variáveis e custos fixos conforme classificação de Faria e Costa (2005). Combustível, óleos lubrificantes, pneus, manutenção e lavagem dos veículos são custos variáveis aos quais ele atribuiu maior importância. De fato, justifica-se a pontuação, pois, conforme visto no tópico 4.1., em setembro deste ano a XPTO teve custos de quase 87 mil Reais com esses itens.

O tamanho dos lotes transportados e a distância percorrida não constam da classificação proposta por Faria e Costa (2005), mas são mencionados pela literatura. Wanke, Nazário e Fleury (2000), apesar de não explicitamente, relacionam a questão dos lotes à gestão de transporte, que, quando não tem uma visão integrada da logística, caracteriza-se pelo transporte fracionado, aumentando o custo unitário do transporte. Já a distância percorrida é considerada por Bowersox e Closs (apud FARIA e COSTA, 2005) como um dos vetores que influenciam os custos logísticos de transporte.

Depreciação de veículos e equipamentos são variáveis mencionadas por Faria e Costa (2005) como custos fixos e o volume e a densidade dos produtos é variável considerada por Bowersox e Closs (apud FARIA e COSTA, 2005) como influenciadora dos custos logísticos de transporte. O mesmo ocorre com as condições do tráfego e as condições das rodovias, também mencionadas por Faria e Costa (2005). Pode-se entender a atribuição de pontuação 3 às variáveis depreciação dos veículos e condições das rodovias, tendo em vista a má qualidade e o mau estado de conservação das rodovias brasileiras em geral, aspectos mencionados no tópico 2.3.1, que implicam custos adicionais de transporte.

Para o respondente, dois fatores possuem menor influência no custo do transporte rodoviário da XPTO: impostos e seguros e mão-de-obra (salários e encargos de empregados). Essas variáveis são mencionadas por Faria e Costa (2005). Porém, de acordo com os dados apresentados no tópico 4.1., justifica-se a menor pontuação atribuída pelo gerente porque a XPTO teve no mês de setembro um custo de quase 22 mil Reais com esses itens, muito abaixo dos custos com combustível, óleos lubrificantes, pneus, manutenção e lavagem dos veículos, 87 mil Reais.

O gerente não assinalou seis alternativas: acondicionamento e manuseio do material; roubo, danos e avarias; quilometragem desenvolvida; tempo do percurso entre origem e destino da carga; pontualidade do serviço; serviço porta- 
a-porta; e pedágios. Mas algumas dessas variáveis influenciam os custos logísticos de transporte de acordo com a literatura, por exemplo, pedágios, quilometragem desenvolvida, volume e a densidade dos produtos, acondicionamento e manuseio de materiais, responsabilidade quanto aos riscos de roubo e tempo de percurso. (FARIA e COSTA, 2005; WANKE, NAZÁRIO e FLEURY, 2000). Somente quanto à quilometragem desenvolvida, apenas no mês de setembro deste ano as carretas da XPTO rodaram 48.026km (tópico 4.1.) o que certamente impacta no custo anual de transporte da empresa.

Pergunta 4: Entre seis alternativas (todas mencionadas pelos autores pesquisados na revisão de literatura) a questão 4 solicitou que o gerente assinalasse que medidas poderiam ser adotadas na XPTO para reduzir os custos de transporte.

O gerente assinalou três alternativas: 1) contratação de serviços terceirizados de transporte; 2) uso de sistemas integrados de gestão (disponibilizando pela internet informações sobre carregamento, localização de veículos e previsão de horários de partida e chegada); e 3) adoção de soluções que otimizem cargas e veículos (por exemplo, adequando pedidos ao tamanho do veículo ou fração a ser transportada e selecionando veículos de menor consumo de combustível).

Conforme abordado, de acordo com Ballou (1993), a utilização de frota própria tem suas vantagens. Sabe-se, no entanto, que a frota própria está associada a um volume considerável de custos. (MÜLLER e MICHEL, 2001). Daí porque falar-se em terceirização dos serviços de transporte. Autores como Ballou (1993) e Fleury, Wanke e Figueiredo (2000) observam que a terceirização pode proporcionar maior flexibilidade no serviço de transporte, aumentando o nível do serviço prestado ao cliente, e livrando a empresa de certas obrigações, como por exemplo, ter que programar as roteirizações.

Os sistemas integrados de gestão são recomendados por Wanke, Nazário e Fleury (2000) e também por Melo e Ferreira Filho (2001), pois são capazes de solucionar problemas de roteirização e programação de veículos de maneira satisfatória, além de proporcionar informações online sobre carregamento, localização de veículos e previsão de horários. Já medidas que equacionem a relação entre cargas e veículos têm sido usadas por diferentes empresas como uma alternativa de redução dos custos de transporte. (ROCKMANN, 2015).

As alternativas de redução de custos de transporte não assinaladas pelo gerente foram: busca de soluções intermodais, uso de roteirizadores e adoção de uma nova política de preços e de descontos sobre o frete cobrado. Embora a 
carga transportada pela XPTO (areia lavada) seja, segundo a Agência Nacional de Transportes Terrestres (2016), adequada à adoção da intermodalidade no transporte, pode-se considerar que essa solução de fato não se aplica à empresa basicamente porque a distância entre a extração, em São Pedro da Aldeia, e a região em que a carga é comercializada (Região dos Lagos e alguns municípios da Região Metropolitana do Rio de Janeiro) é pequena, além de não oferecer infraestrutura para o uso de outro transporte que não seja o rodoviário.

O fato de o gerente não ter assinalado o uso de roteirizadores explica-se no caso de a XPTO já utilizar esses equipamentos. Quanto a uma nova política de preços sobre o frete cobrado, sugerida por Müller e Michel (2001) para contribuir com a redução dos custos de transporte, talvez o gerente acredite que a atual política seja razoável, não demandando maiores reavaliações.

Pergunta 5: Entre seis alternativas, a questão 5 indagou ao gerente de que maneira ele, pessoalmente, poderia contribuir para a redução dos custos de transporte da empresa. As opções assinaladas foram: monitorando e controlando as atividades operacionais de transporte; insistindo junto ao proprietário a adoção da(s) medida(s) assinaladas na questão anterior; e identificando problemas de transporte que necessitam da intervenção direta do gestor da empresa.

A primeira e a última opção assinaladas demonstram a responsabilidade do gerente com o setor que comanda. Quanto à segunda alternativa assinalada denota que o gerente gostaria de ser ouvido em suas opiniões pelo proprietário, o que talvez pudesse contribuir para a redução de falhas e de custos do transporte da empresa.

\subsubsection{Respostas dos caminhoneiros e análise}

Os dois caminhoneiros são especializados na direção de veículos pesados de carga. Um tem 25 de experiência na função e o outro, 17 anos. Um está há cinco anos na XPTO e o outro há três anos. Na empresa, ambos estão lotados como motoristas de carretas.

Pergunta 1: Entre cinco alternativas, solicitou-se que os motoristas assinalassem as principais dificuldades enfrentadas no trabalho. Um caminhoneiro assinalou: falta de controle da jornada semanal de trabalho e do tempo diário de direção e risco de acidentes. O outro assinalou: falta de controle da jornada semanal de trabalho e do tempo diário de direção, ausência de rotina quanto a horários de refeição e descanso e risco de acidentes. Os 
caminhoneiros não assinalaram problemas de saúde como uma dificuldade e falta de organização e comando nas operações de transporte (por exemplo, em relação ao carregamento e descarregamento da carga). O fato de não terem assinalado esta última variável pode denotar que eles consideram satisfatório o desempenho do gerente de logística, uma vez que é ele o responsável por essa tarefa, ou mesmo que consideram satisfatório um processo que já pode ter sido implantado na firma, independentemente de qualquer intervenção de algum funcionário.

A escolha da variável risco de acidentes é bastante compreensível, já que este risco é inerente à atividade que eles desenvolvem. Quanto às outras duas alternativas assinaladas como dificuldades - falta de controle da jornada semanal de trabalho e do tempo diário de direção e ausência de rotina quanto a horários de refeição e descanso - podem apontar para um problema do setor e também da própria XPTO, que deve tentar solucioná-lo em comum acordo com os caminhoneiros para evitar insatisfações no trabalho.

Pergunta 2: Entre 15 alternativas, solicitou-se aos caminhoneiros que apontassem que fatores influenciam os custos do transporte na empresa e em que grau de importância, sendo 1 os de menor influência, 2 de influência mediana e 3 de maior influência.

Um caminhoneiro não assinalou: distância percorrida, preço do combustível, tamanho dos lotes transportados, má conservação das rodovias pontualidade do serviço, pedágios e rotas escolhidas. O outro caminhoneiro não assinalou: condições dos veículos da empresa, roubo, danos e avarias da carga, condições do tráfego, tamanho dos lotes transportados, má conservação das rodovias, tempo gasto no percurso entre origem e destino, pontualidade do serviço, pedágios e rotas escolhidas. Ao não considerarem esses fatores como influenciadores dos custos de transporte da XPTO, ambos demonstram não ter noção exata de que essas variáveis podem de fato influenciar nos custos dos transportes, conforme apontado por Faria e Costa (2005), Wanke, Nazário e Fleury (2000) e Bowersox e Closs (apud FARIA e COSTA, 2005).

Um caminhoneiro assinalou como de maior influência nos custos de transporte da XPTO o volume e peso do produto transportado (aspecto mencionado por Faria, Robles e Bio, 2004 e Bowersox e Closs, citados por Faria e Costa, 2005) e o desempenho dos motoristas da empresa, o que denota a sua própria responsabilidade nesse processo. Com influência mediana, ele assinalou: condições dos veículos da empresa, quilometragem desenvolvida e envelhecimento dos veículos e equipamentos, aspectos também tratados pelos 
autores consultados. De menor influência, assinalou roubo, danos e avarias da carga e tempo gasto no percurso entre origem e destino, o que não é compatível com as opiniões de Bowersox e Closs (apud FARIA e COSTA, 2005) e Wanke, Nazário e Fleury (2000).

O outro caminhoneiro assinalou como de maior influência: preço do combustível e desempenho dos motoristas da empresa, a primeira variável correspondendo a um custo dos mais elevados (WANKE e FLEURY, 2006) e a outra denotando, a exemplo de seu colega, a sua própria responsabilidade no processo. De influência mediana, ele assinalou: distância percorrida, volume e peso do produto transportado (aspectos mencionados por Faria, Robles e Bio, 2004 e Bowersox e Closs, citados por Faria e Costa, 2005) e envelhecimento dos veículos e equipamentos, aspecto citado por Faria e Costa (2005). De menor influência, este caminhoneiro assinalou a quilometragem desenvolvida, aspecto mencionado por Faria e Costa (2005).

Pergunta 3: Foi solicitado aos caminhoneiros que, entre seis, alternativas, assinalassem que medidas a XPTO poderia adotar para reduzir os custos de transporte. Ambos assinalaram a opção planejar melhor as rotas, a exemplo do que recomendam Müller e Michel (2001). Esse aspecto talvez denote uma crítica ao modelo adotado pelo gerente de logística da empresa na roteirização das entregas do produto. Ambos também assinalaram a opção recompensar os motoristas que reduzem os custos que eles próprios podem reduzir, tema não focado por nenhum dos autores pesquisados, mas que talvez revele que a empresa pode repensar suas políticas de recursos humanos.

Um caminhoneiro assinalou ainda a opção diminuir a frota e outro a opção oferecer cursos e treinamentos para os motoristas. A redução da frota talvez não seja possível para a XPTO no momento em função da demanda por seu produto. A empresa até poderia vender as três carretas que hoje estão ociosas, substituindo-as por equipamentos de transporte de menor capacidade de transporte em busca de maior agilidade e equipamentos com capacidade completa de carga, sem ociosidade de espaço e, ao mesmo tempo, levantando algum capital, mas talvez não possa reduzir o número de carretas em uso. Quanto à opção oferecer cursos e treinamentos aos motoristas, esta é uma sugestão de Müller e Michel (2001) para reduzir os custos de transporte rodoviário.

Pergunta 4: Entre seis alternativas, solicitou-se que os caminhoneiros assinalassem como eles próprios poderiam contribuir para a redução dos custos de transporte da XPTO. A opção consertando eu mesmo problemas na carreta 
que eu sei consertar não foi assinalada pelos dois caminhoneiros. Percebe-se nesse sentido que ambos se limitam ao seu dever profissional, pois são motoristas, e não mecânicos.

Ambos assinalaram as opções: dirigindo em velocidade moderada para não gastar combustível, cuidando da carreta sob sua responsabilidade, e tendo um comportamento correto e seguro ao volante. Um assinalou ainda a opção dirigindo com cautela para não gastar demais os pneus do veículo e outro a opção avisando logo o gerente sobre problemas mais sérios na carreta que ele mesmo identifica. Desses resultados conclui-se: que eles têm noção do potencial de aumento de custos com o consumo de combustível e com a depreciação de equipamentos, a exemplo do mencionado por Faria e Costa (2005), que têm o sentido de responsabilidade com o veículo que dirigem, e de que estão sob o comando de um superior imediato (o gerente de logística). 


\section{Conclusões e recomendações para novos estudos}

Esta pesquisa abordou os custos logísticos de transporte, focando estratégias de otimização desses custos no âmbito da Empresa XPTO, discutindo e sugerindo mudanças para tanto.

$\mathrm{O}$ estudo foi dividido em duas partes. A primeira voltou-se à revisão de literatura. Foram abordados os aspectos históricos e conceituais sobre logística empresarial, custos logísticos, com maior enfoque sobre custos logísticos de transporte e sobre o transporte rodoviário, o mais amplamente adotado no Brasil. Finalizou-se esta parte com uma abordagem sobre medidas de otimização dos custos logísticos do transporte rodoviário, sugeridas por diferentes autores.

Esta revisão confirmou que a logística é compreendida atualmente como um componente estratégico, principalmente pelas oportunidades que proporciona para as empresas na gestão da cadeia de suprimentos, desde que se tenha uma visão integrada da logística. Outro ponto evidenciado é que as operações logísticas têm custos elevados para as empresas, daí advindo a necessidade de gerenciarem esses custos, ação considerada imprescindível por todos os especialistas no tema.

A revisão de literatura também apontou que os custos logísticos de transporte são reconhecidamente os que mais pesam dentre todos os outros custos logísticos que foram mencionados. Como esses custos correspondem à maior parcela dos custos logísticos na maioria das organizações, refletir sobre eles foi muito relevante para alcançar o objetivo principal da pesquisa.

A fundamentação teórica também deixou claro para o autor que existem medidas de redução dos custos logísticos no transporte rodoviário. Muito embora não haja literatura abundante que especificamente trate sobre esse tema, foram apresentadas algumas visões que se consideram relevantes pela contribuição que oferecem às análises científicas sobre a otimização dos custos de transporte rodoviários.

Na pesquisa empírica realizada no estudo de caso da Empresa XPTO, que utiliza o transporte rodoviário para a comercialização de seu produto - areia lavada, com base em dois questionários aplicados a diferentes cargos de logística da empresa pelos funcionários (Gerente e dois Caminhoneiros), vários 
aspectos das respostas de cada um deles foram comentados e analisados ao longo da apresentação e análise dos resultados. Considera-se, a título conclusivo, que a Empresa XPTO pode efetivar ações que reduzam seus custos com o transporte rodoviário sendo, entre elas:

- A principal delas, a mudança nos métodos operacionais atualmente empregados e identificados como uma dificuldade pelo gerente de logística.

- A mudança passa por várias questões mencionadas pelos participantes da pesquisa, que vão desde a contratação de serviços terceirizados até o oferecimento de cursos e treinamentos para os motoristas ou, ainda, de uma recompensa para os mais cuidadosos, com vistas à redução desse tipo de custo.

- Trocar três caminhões que estão ociosos, em função do seu tamanho, por caminhões menores, que permitam um melhor processo de programação de entrega, por serem de menores custos operacionais em função da quantidade de carga solicitada, o que melhoria a velocidade no tempo de entrega e, também diminuiria seus custos operacionais pelo melhor aproveitamento da capacidade de carga, permitindo carga completa do equipamento de transporte e o veículos de maior porte podendo ser terceirizados.

\subsection{Comentários Finais e Recomendações}

Não foi propósito desta pesquisa analisar todos os aspectos que envolvem os custos logísticos de transporte das empresas e nem seria viável, sabendo-se que os custos logísticos são um tema pouco abordado pela literatura. Considerase, entretanto, que os objetivos propostos foram alcançados, principalmente tendo em vista o estudo de caso realizado, cujos resultados podem contribuir efetivamente para as reflexões em torno do tema, apesar de não se poder generalizá-los.

Recomenda-se, assim, que novas pesquisas a respeito sejam realizadas. Sugere-se especialmente o desenvolvimento de pesquisas em outras empresas que utilizam, além do modal rodoviário, outros modais de transporte. 


\section{Referências Bibliográficas}

ANTT, Agência Nacional de Transportes Terrestres. Transporte Muldimodal. Disponível em < https://appweb.antt.gov.br/faq/multimodal.asp $>$ Acesso em 26 de setembro de 2016.

BALLOU, R.H. Gerenciamento da Cadeia de Suprimentos/Logística Empresarial. São Paulo: Atlas, 2007.

BALLOU, R.H. Logística Empresarial: transportes, administração de materiais e distribuição física. São Paulo: Atlas, 1993.

BRASIL, Ministério dos Transportes. Plano Nacional de Logística e Transportes. Brasília: Secretaria de Política Nacional de Transportes, 2012.

BRESSAN, F. O método do estudo de caso e seu uso em Administração. Revista Administração: Ensino \& Pesquisa (RAEP), v. 5, p. 24-40, Salvador, janeiro/março de 2004.

BULLER, L.S. Logística Empresarial. Curitiba: IESDE, 2012.

CAVANHA FILHO, A.O. Logística - Novos modelos. Rio de Janeiro: Qualitymark, 2001.

CHRISTOPHER, M. Logística e Gerenciamento da Cadeia de Suprimentos: estratégias para a redução de custos e melhorias de serviços. São Paulo: Pioneira, 1997.

CITTADIN, A.; ZANETTE, R.V.R.; RITTA, C.O. Principais custos logísticos que integram a cadeia de valor de uma empresa comercial exportadora. Anais do XVII Congresso Brasileiro de Custos. Fortaleza: 2009.

FARIA, A.C.; COSTA, M.F.G. Gestão de Custos Logísticos. São Paulo: Atlas, 2005.

FARIA, A.C.; ROBLES, L.T.; BIO, S.R. Custos logísticos: discussão sob uma ótica diferenciada. Anais do XI Congresso Brasileiro de Custos. Porto Seguro, 2004.

FLEURY, P.F.; WANKE, P.; FIGUEIREDO, K.F. Logística Empresarial: a perspectiva brasileira. São Paulo: Atlas, 2000.

FUNDAÇÃO DOM CABRAL. Pesquisa Custos Logísticos no Brasil 2015. Belo Horizonte: Fundação Dom Cabral, 2015.

GOMES, C.F.S.; RIBEIRO, P.C.C. Gestão da Cadeia de Suprimentos Integrada à Tecnologia da Informação. São Paulo: Pioneira Thomson Learning, 2004. 
GUARNIERI, P. et al. WMS - Wharehouse Management System: adaptação proposta para o gerenciamento da logística reversa. Revista Produção, v. 16, n. 1, p. 126-139, janeiro/abril de 2006.

HUBER, B. Iniciativas para redução de custos de transporte. Grupo llos. 24 mai. 2016. Disponível em: < http://www.ilos.com.br/web/iniciativas-para-reducaode-custos-de-transporte/> Acesso em 29 de setembro de 2016.

LEITE, P.R. Logística Reversa: meio ambiente e competitividade. São Paulo: Prentice Hall, 2003.

MELO, A.C.S.; FERREIRA FILHO, V.J.M.F. Sistemas de roteirização e programação de veículos. Revista Pesquisa Operacional, v. 21, n. 2, p. 223232, julho/dezembro de 2001.

MÜLLER, C.J.; MICHEL, F.D. Análise de custos para empresas de transporte rodoviário de cargas. Anais do XXI ENEGEP. Salvador, 2001.

NOVAES, A.G. Logística e Gerenciamento da Cadeia de Distribuição: estratégia, operação e avaliação. Rio de Janeiro: Elsevier, 2014.

ROCHA, A.L.P.; GUIDALI, H. Uma radiografia do setor de operadores logísticos no Brasil na virada do século XX. Anais do XXVI EnANPAD. Salvador: Anpad, 2002.

ROCKMANN, R. Alto custo dos transportes impulsiona busca por alternativas às rodovias. Revista Carta Capital, 06/11/2015. Disponível em: < http://www.cartacapital.com.br/especiais/infraestrutura/alto-custo-dostransportes-impulsiona-busca-por-alternativas-as-rodovias-731.html> Acesso em 30 de setembro de 2016.

SOUZA, M.A.; SCHNORR, C.; FERREIRA, F.B. Práticas de gestão de custos logísticos: estudo de caso de uma empresa do setor alimentício. Revista Contemporânea de Contabilidade, v. 10, n. 19, p. 03-32, Florianópolis, janeiro/abril de 2013.

VERGARA, S.C. Projetos e Relatórios de Pesquisa em Administração. São Paulo: Atlas, 2010.

WANKE, P. Fatores de satisfação com o uso de autônomos no transporte rodoviário de cargas. Revista Produção, v. 22, n. 3, p. 584-595, maio/agosto de 2012.

WANKE, P. Logística e Transporte de Cargas no Brasil: produtividade e eficiência no século XXI. Coleção Coppead de Administração. São Paulo: Atlas, 2010.

WANKE, P.; FLEURY, P.F. Transporte de cargas no Brasil: estudo exploratório das principais variáveis relacionadas aos diferentes modais e às suas estruturas de custos. In: DE NEGRI, J.A.; KUBOTA, L.C. (orgs.). Estrutura e Dinâmica do Setor de Serviços no Brasil. Brasília: IPEA, 2006.

WANKE, P. F.; MAGALHÃES, A. Logística para Micro e Pequenas Empresas. São Paulo: Atlas, 2012. 
WANKE, P.; NAZÁRIO, P.; FLEURY, P.F. O papel do transporte na estratégia logística. Grupo llos. 10 dez. 2000. Disponível em: < http://www.ilos.com.br/web/o-papel-do-transporte-na-estrategia-logistical/> Acesso em: 19 de agosto de 2016. 


\section{Apêndice 1}

\section{QUESTIONÁRIO PARA O GERENTE}

\section{DADOS GERAIS:}

Especialização:

Tempo de experiência em logística:

Cargo ou função que ocupa na empresa:

Tempo de empresa:

1) Dentre as alternativas abaixo assinale as principais dificuldades enfrentadas por você no comando do setor de transportes da empresa.

( ) Falta de mão-de-obra qualificada

( ) Descuido dos motoristas com as carretas

( ) Reclamação de clientes quanto ao transporte da carga (falta de pontualidade, falta de qualidade etc)

( ) Gerenciamento de crises no setor

( ) Ineficácia dos métodos operacionais empregados

2) A empresa transporta as cargas por meio do modal rodoviário. Dentre as alternativas abaixo assinale com um $X$ os benefícios desse modal para a empresa. Depois, atribua em números a importância de cada benefício escolhido, sendo 1 pouco importante, 2 importante e 3 muito importante.

\begin{tabular}{|l|l|l|}
\hline \multicolumn{1}{|c|}{ Benefícios } & Grau de importância \\
\hline $\begin{array}{l}\text { Comodidade (serviço porta-a-porta, sem } \\
\text { necessidade de carregamento e } \\
\text { descarregamento entre origem e destino) }\end{array}$ & & \\
\hline Velocidade & & \\
\hline $\begin{array}{l}\text { Disponibilidade (quantidade de locais em que o } \\
\text { modal está presente) }\end{array}$ & & \\
\hline $\begin{array}{l}\text { Confiabilidade (proporciona programações } \\
\text { variáveis de entrega) }\end{array}$ & & \\
\hline $\begin{array}{l}\text { Capacidade (atende a qualquer tamanho e tipo } \\
\text { de carga) }\end{array}$ & & \\
\hline $\begin{array}{l}\text { Frequência (capacidade de operar a qualquer } \\
\text { hora, em qualquer dia) }\end{array}$ & & \\
\hline
\end{tabular}


3) Entre as alternativas abaixo assinale com um $X$ os fatores que mais influenciam os custos do transporte rodoviário para a empresa. Depois atribua em números o grau de influência de cada fator assinalado, sendo 1 os que exercem menos influência, 2 os que exercem influência mediana e 3 os que exercem muita influência.

\begin{tabular}{|l|l|l|}
\hline \multicolumn{2}{|c|}{ Fatores } & Grau de influência \\
\hline Distância percorrida & & \\
\hline Volume e densidade do produto transportado & & \\
\hline Acondicionamento e manuseio do material & & \\
\hline Condições dos veículos da empresa & & \\
\hline Roubo, danos e avarias & & \\
\hline Condições do tráfego & & \\
\hline Quilometragem desenvolvida & & \\
\hline Tamanho dos lotes transportados & & \\
\hline Impostos e seguros & & \\
\hline $\begin{array}{l}\text { Combustível, óleos lubrificantes, pneus, } \\
\text { manutenção e lavagem dos veículos }\end{array}$ & & \\
\hline $\begin{array}{l}\text { Tempo do percurso entre origem e destino da } \\
\text { carga }\end{array}$ & & \\
\hline Pontualidade do serviço & & \\
\hline Serviço porta-a-porta & & \\
\hline Pedágios & & \\
\hline Condições das rodovias & & \\
\hline $\begin{array}{l}\text { Mão-de-obra (salários e encargos de } \\
\text { empregados) }\end{array}$ & & \\
\hline Depreciação de veículos e equipamentos & \\
\hline
\end{tabular}

4) Assinale entre as alternativas abaixo que medidas você acha que a empresa poderia adotar para reduzir seus custos de transporte.

( ) Contratação de serviços terceirizados de transporte

( ) Busca de soluções intermodais (utilizando mais um modal de transporte além do rodoviário)

( ) Uso de sistemas computacionais, como os sistemas de roteirização e programação de veículos (roteirizadores)

( ) Uso de sistemas integrados de gestão empresarial que dispõem pela internet informações sobre carregamento, localização de veículos e previsão de horários de partida e chegada

( ) Adoção de uma nova política de preços e de descontos sobre o frete cobrado 
( ) Adoção de soluções que otimizem cargas e veículos, por exemplo, adequando pedidos ao tamanho do veículo ou fração a ser transportada e selecionando veículos de menor consumo de combustível

5) Na qualidade de gerente de logística, assinale, dentre as alternativas abaixo, de que forma você, pessoalmente, pode contribuir para a redução dos custos de transporte da empresa.

( ) Mostrando que eu emprego os recursos de transporte com eficiência econômica

( ) Monitorando e controlado as atividades operacionais de transporte

( ) Insistindo junto ao proprietário a adoção da(s) medida(s) que assinalei na questão anterior

( ) Fornecendo ao proprietário dados que determinam causas e origem de erros em relação ao transporte

( ) Identificando problemas de transporte que necessitam da intervenção direta do gestor da empresa

( ) Identificando oportunidades de melhorar o nível dos serviços prestados ao cliente 


\section{Apêndice 2}

\section{QUESTIONÁRIO PARA OS CAMINHONEIROS}

\section{DADOS GERAIS:}

Especialização:

Tempo de experiência como motorista de caminhões:

Cargo ou função que ocupa na empresa:

Tempo de empresa:

1) Dentre as alternativas abaixo assinale as principais dificuldades que você enfrenta no seu trabalho

( ) Falta de organização e comando nas operações de transporte (por exemplo, em relação ao carregamento e descarregamento da carga)

( ) Falta de controle da jornada semanal de trabalho e do tempo diário de direção

( ) Ausência de rotina quanto a horários de refeição e descanso

( ) Risco de acidentes

( ) Problemas de saúde

2) Entre as alternativas abaixo assinale com um $X$ os fatores que para você mais influenciam os custos do transporte na empresa. Depois atribua em números o grau de influência de cada fator assinalado, sendo 1 os que exercem menos influência, 2 os que exercem influência mediana e 3 os que exercem muita influência.

\begin{tabular}{|l|l|l|}
\hline \multicolumn{2}{|c|}{ Fatores } & Grau de influência \\
\hline Distância percorrida & & \\
\hline Volume e peso do produto transportado & & \\
\hline Preço do combustível & & \\
\hline Condições dos veículos da empresa & & \\
\hline Roubo, danos e avarias da carga & & \\
\hline Condições do tráfego & & \\
\hline Quilometragem desenvolvida & & \\
\hline Tamanho dos lotes transportados & & \\
\hline Envelhecimento dos veículos e equipamentos & & \\
\hline Má conservação das rodovias & & \\
\hline Tempo gasto no percurso entre origem e & & \\
\hline
\end{tabular}




\begin{tabular}{|l|l|l|}
\hline destino & & \\
\hline Pontualidade do serviço & & \\
\hline Pedágios & & \\
\hline Rotas escolhidas & & \\
\hline Desempenho dos motoristas da empresa & & \\
\hline
\end{tabular}

3) Assinale entre as alternativas abaixo que medidas você acha que a empresa poderia adotar para reduzir os custos de transporte.

( ) Planejar melhor as rotas

( ) Ter mais controle e monitoramento sobre as operações de transporte

( ) Oferecer cursos e treinamentos para os motoristas sobre como dirigir corretamente e como reduzir custos do transporte rodoviário

( ) Diminuir a frota

( ) Recompensar os motoristas que reduzem os custos que eles próprios podem reduzir

( ) Contratar motoristas mais experientes

4) Assinale, dentre as alternativas abaixo, de que forma você, pessoalmente, pode contribuir para a redução dos custos de transporte da empresa.

( ) Dirigindo em velocidade moderada para não gastar combustível

( ) Cuidando da carreta que está sob minha responsabilidade

( ) Dirigindo com cautela para não gastar demais os pneus do veículo

( ) Avisando logo o gerente sobre problemas mais sérios na carreta identificados por mim

( ) Consertando eu mesmo problemas na carreta que eu sei consertar

( ) Tendo um comportamento correto e seguro ao volante (por exemplo, evitando o consumo de bebidas alcóolicas durante o trabalho) 